BMC

Evolutionary Biology

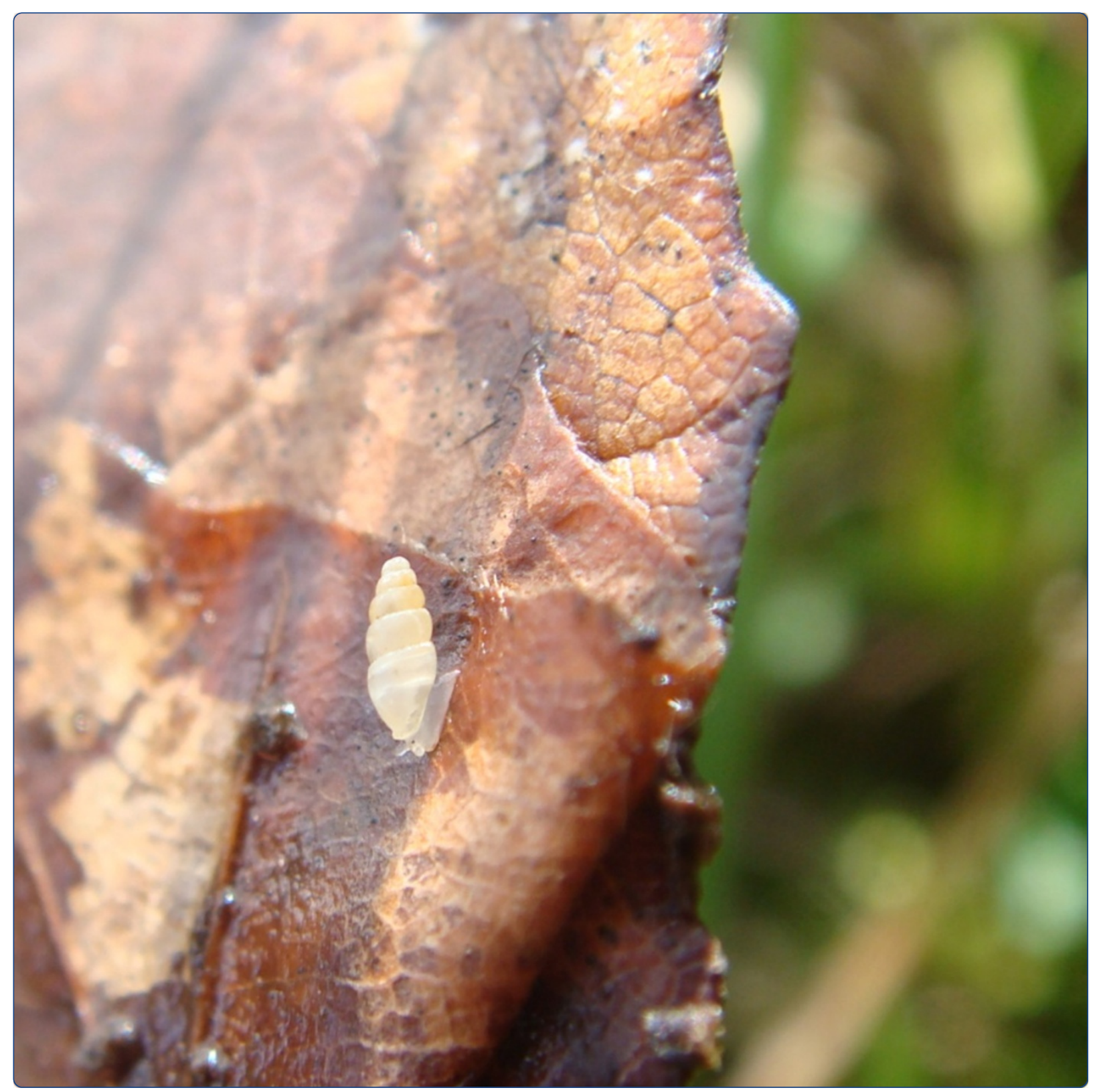

Evolution of microgastropods (Ellobioidea, Carychiidae): integrating taxonomic, phylogenetic and evolutionary hypotheses

Weigand et al.

() Biomed Central 


\title{
Evolution of microgastropods (Ellobioidea, Carychiidae): integrating taxonomic, phylogenetic and evolutionary hypotheses
}

Alexander M Weigand ${ }^{1 *}$, Adrienne Jochum ${ }^{1}$, Rajko Slapnik ${ }^{2}$, Jan Schnitzler ${ }^{1,3}$, Eugenia Zarza ${ }^{1,3}$ and Annette Klussmann-Kolb $b^{1,3}$

\begin{abstract}
Background: Current biodiversity patterns are considered largely the result of past climatic and tectonic changes. In an integrative approach, we combine taxonomic and phylogenetic hypotheses to analyze temporal and geographic diversification of epigean (Carychium) and subterranean (Zospeum) evolutionary lineages in Carychiidae (Eupulmonata, Ellobioidea). We explicitly test three hypotheses: 1) morphospecies encompass unrecognized evolutionary lineages, 2) limited dispersal results in a close genetic relationship of geographical proximally distributed taxa and 3) major climatic and tectonic events had an impact on lineage diversification within Carychiidae.
\end{abstract}

Results: Initial morphospecies assignments were investigated by different molecular delimitation approaches (threshold, ABGD, GMYC and SP). Despite a conservative delimitation strategy, carychiid morphospecies comprise a great number of unrecognized evolutionary lineages. We attribute this phenomenon to historic underestimation of morphological stasis and phenotypic variability amongst lineages. The first molecular phylogenetic hypothesis for the Carychiidae (based on COI, $16 \mathrm{~S}$ and $\mathrm{H} 3$ ) reveals Carychium and Zospeum to be reciprocally monophyletic. Geographical proximally distributed lineages are often closely related. The temporal diversification of Carychiidae is best described by a constant rate model of diversification. The evolution of Carychiidae is characterized by relatively few (long distance) colonization events. We find support for an Asian origin of Carychium. Zospeum may have arrived in Europe before extant members of Carychium. Distantly related Carychium clades inhabit a wide spectrum of the available bioclimatic niche and demonstrate considerable niche overlap.

Conclusions: Carychiid taxonomy is in dire need of revision. An inferred wide distribution and variable phenotype suggest underestimated diversity in Zospeum. Several Carychium morphospecies are results of past taxonomic lumping. By collecting populations at their type locality, molecular investigations are able to link historic morphospecies assignments to their respective evolutionary lineage. We propose that rare founder populations initially colonized a continent or cave system. Subsequent passive dispersal into adjacent areas led to in situ pan-continental or mountain range diversifications. Major environmental changes did not influence carychiid diversification. However, certain molecular delimitation methods indicated a recent decrease in diversification rate. We attribute this decrease to protracted speciation.

Keywords: Integrative taxonomy, Protracted speciation, Subterranean environment, Cryptic diversity, DNA barcoding, Allopatric diversification, Carychium, Zospeum, Phylogeny, Gastropoda

\footnotetext{
* Correspondence: A.Weigand@bio.uni-frankfurt.de

${ }^{1}$ Department of Phylogeny and Systematics, Institute for Ecology, Evolution and Diversity, Biosciences, Goethe-University Frankfurt, Max-von-Laue Straße 13, 60438, Frankfurt am Main, Germany

Full list of author information is available at the end of the article
} 


\section{Background}

Climatic and geological changes are considered to be major drivers of biological diversification. Many wellcharacterized radiations were initiated in aftermath of major geologic events [1-3]. Current biodiversity patterns reflect these consequential processes. While taxa with low dispersal ability may be particularly sensitive to changes in their environment, historically-formed patterns within these taxa are known to remain well preserved [4,5]. The taxon Ellobioidea (Gastropoda, Eupulmonata) comprises a group of morphologically and ecologically highly diverse snails, known to have successfully invaded the marine, brackish water and terrestrial habitats [6,7]. Species are traditionally classified into five taxonomic groups, the Pythiidae, the Laemodontidae, the Melampodidae, the Ellobiidae and the Carychiidae. These taxa have been recognized either as families within Ellobioidea or as subfamilies within the family Ellobiidae [6-8]. To avoid confusion, we will here refer to the taxon Ellobioidea and to families. Taxonomic descriptions and systematic classifications were exclusively based on morphological (anatomical and conchological) characters while extant species show a mosaic pattern of plesiomorphic and apomorphic features resulting from convergent evolution $[6,7,9,10]$. Due to the tenuous nature of morphological characters, phylogenetic reconstructions are extremely difficult [6,11]. Moreover, the high degree of homoplasy in morphological characters and frequent low variability has led to the description of approximately 800 species names available in the literature, whereby 250 are likely to be valid [12]. The most comprehensive molecular study for the Ellobioidea suggests a monophyletic origin of the entire group. However, the relationships among the five traditional ellobioid taxa are still unclear [13].

One lineage of the Ellobioidea, the Carychiidae Jeffreys, 1830 has successfully accomplished a complete transition onto land. Extant carychiid snails inhabit aphotic and permanently wet epigean (Carychium) or subterranean (Zospeum) environments throughout their Holarctic distribution. This dramatic shift from a marine to a terrestrial habitat has occurred independently of the stylommatophoran land-snails of the Eupulmonata [13,14]. As for all Ellobioidea, taxonomic and systematic descriptions of Carychiidae are based upon characters of the mature shell, which in the case of carychiid gastropods, are suspected to vary according to environmental conditions [15-17]. The first attempt to characterize carychiid taxa using DNA barcodes supported $90 \%$ of traditional morphospecies assignments [18]. Nevertheless, the same study only addressed a single population or a few populations per morphospecies. Phenotypic variability (in Carychium) and morphological stasis (in Zospeum) were identified as potential explanations for discrepancies in morphological and molecular taxonomy. In particular, Zospeum displayed high intraspecific genetic diversity within single morphospecies, as reflected by several cave-endemic evolutionary lineages (ELs). In the case of European Carychium, DNA barcoding revealed a previously overlooked taxonomic entity and helped to reevaluate the taxonomic status of questionable morphospecies [18,19]. Additionally, the phenotypically variable Carychium shell was shown to span a wide range of shell dimension and proportions, encompassing three morphospecies. Hence, it is very likely that the Carychiidae harbor a considerable number of morphologically unrecognized ELs.

A gastropod's migratory ability is correlated with its shell size [20,21]. Due to their small size, the active dispersal abilities of carychiid snails are highly limited. Slapnik [22] conducted investigations on Zospeum isselianum activity within a cave showing moving distances measuring 1 to 15 $\mathrm{cm}$ per week (on average $0.7 \mathrm{~cm}$ per day). In a comparative phylogeography of two European Carychium species, Weigand et al. [23] revealed that the local population structure is often formed by only a few mtDNA haplotypes suggesting that adjacent populations may only exhibit infrequent gene flow. Nevertheless, minute gastropods are well adapted to passive dispersal (e.g. [24,25]), a mechanism that best explains the foundation of transatlantic European Carychium populations in North America $[26,27]$ and the postglacial recolonization of Northern Europe [23]. Although passive dispersal events are relatively rare, these, along with limited mobility, could well contribute to a higher incidence of isolated populations and narrow endemism.

Here, we use an integrative approach combining taxonomic, phylogenetic and evolutionary hypotheses to assess the diversification of ELs in Carychiidae. This process first assigned all specimens to phenotype hypotheses. A conservative genetic delimitation method is used to evaluate the initial morphospecies assignments and to identify distinct ELs $[28,29]$. This approach allows us to include otherwise morphologically unrecognized ELs, whose absence during phylogenetic tree reconstructions could yield misleading results [30]. Based on the identified lineages, a molecular phylogenetic hypothesis for Carychiidae is then reconstructed to test three evolutionary hypotheses: 1) morphospecies encompass unrecognized ELs, 2) limited dispersal results in a close genetic relationship of geographical proximally distributed taxa and 3) major climatic and tectonic events had an impact on lineage diversification within Carychiidae.

\section{Results}

\section{Molecular identification of evolutionary lineages and species delimitation}

To address morphologically unrecognized ELs, the initial morphospecies identifications (Figures 1 and 2, Table 1) were examined applying a combination of five molecular 
delimitation approaches on mitochondrial sequence data. The 3.2\% K2P threshold value identified 45 partitions (Figures 3 and 4). The Automatic Barcoding Gap Detection (ABGD) method consistently revealed 43 ELs for all tested combinations. Two versions of the General Mixed Yule-Coalescent (GMYC) model were applied. Both variants performed significantly better than the null model of a single coalescent population $\left(\mathrm{L}_{0}=1275.858\right.$, both p-values $<0.0001)$, but led to to a high partitioning of the dataset resulting in $64\left(\mathrm{~L}_{\mathrm{GMYCs}}=1315.46\right)$ and 78 clusters $\left(\mathrm{L}_{\mathrm{GMYCm}}=1321.515\right)$, respectively. No significant improvement was found when applying GMYCm instead of GMYCs (Chi-square $=12.1081, \mathrm{df}=6$ and $\mathrm{p}=0.0596$ ). Finally, the Statistical Parsimony (SP) approach delimited 51 ELs mostly congruent to the $3.2 \%$ threshold and ABGD results.
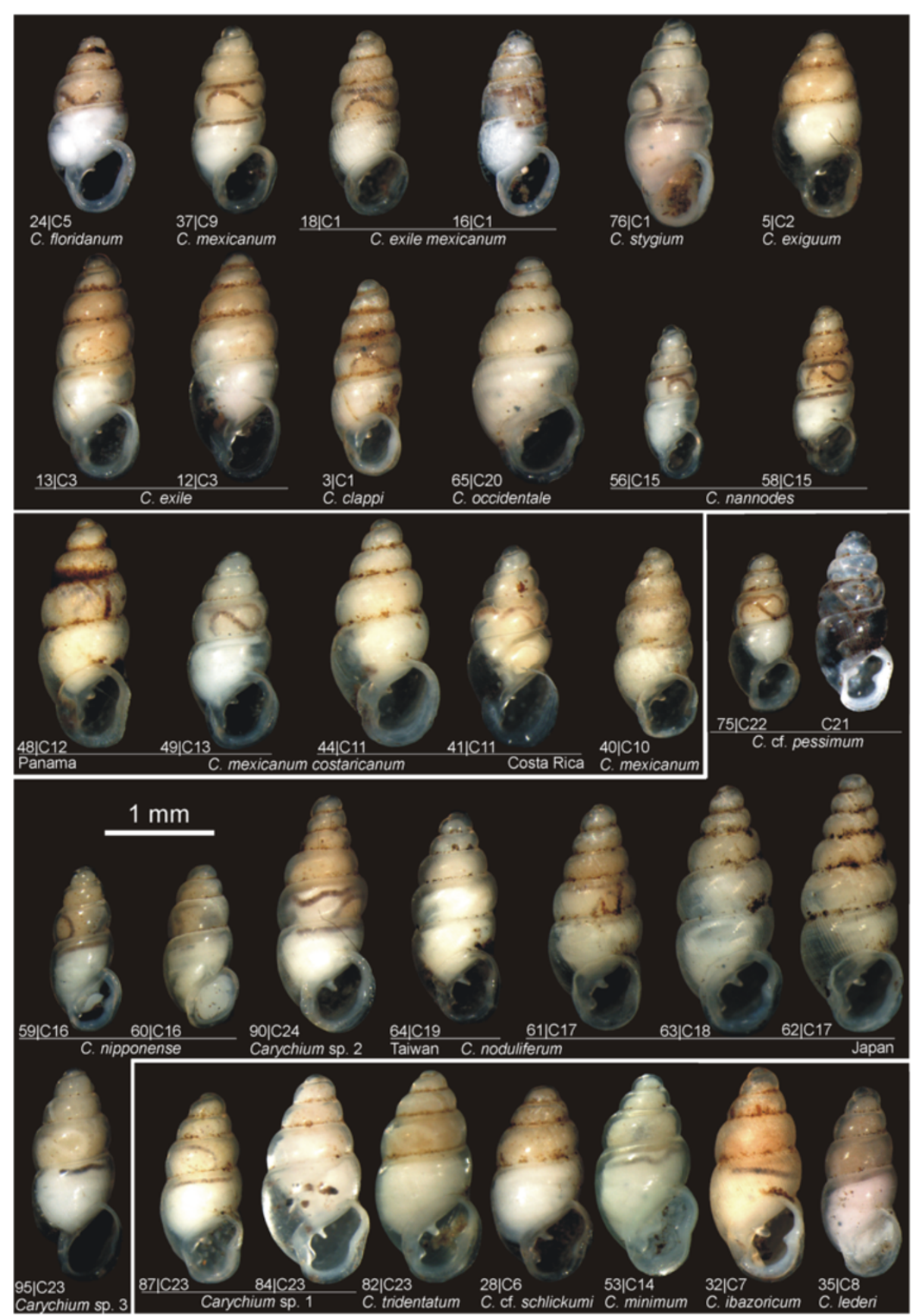

Figure 1 Carychium morphospecies and corresponding genetic lineages. Traditionally identified morphospecies and their respective delimitated evolutionary lineage (C1-C25) and specimen identifier are visualized. The lineage C21 (C. cf. pessimum) is figured by an empty shell of the same population instead of an analyzed individual. 

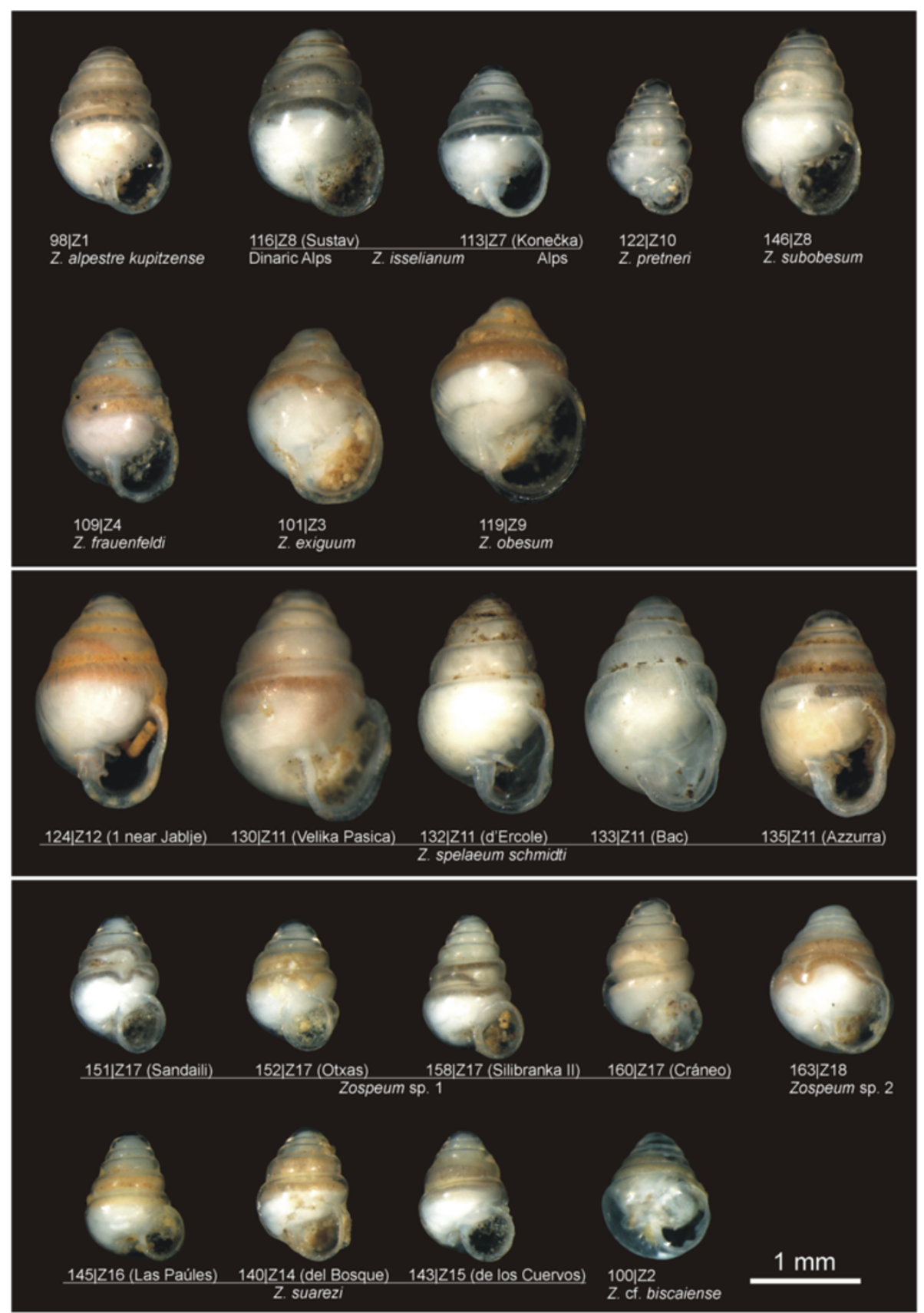

Figure 2 Zospeum morphospecies and corresponding genetic lineages. Traditionally identified morphospecies and their respective delimitated evolutionary lineage (Z1-Z18) and specimen identifier are visualized. In some cases the cave name is provided in brackets.

A conservative delimitation strategy was used to combine the partitions of all five approaches. Since all molecular methods tended to split morphospecies, we decided to risk taxonomic lumping, and classified ELs as the most comprehensive grouping of specimens predicted by any of the five delimitation methods. Thus, the 28 carychiid morphospecies (Figures 1 and 2, Table 1) comprised 43 distinct ELs (Figures 3 and 4, Table 2). In total, 17 morphospecies were each recovered as a single
EL (Table 2; 'matches'). The morphologically distinct, but so far, undescribed Carychium sp. 2, Carychium sp. 3 (both from China), Zospeum sp. 1 and Zospeum sp. 2 (both from Cantabrian Mts.) were also genetically revealed as separate clusters. Divergent ELs within a single morphospecies hypothesis were found for eight morphospecies (32\%): Carychium exile mexicanum (2 lineages), C. mexicanum (2), C. mexicanum costaricanum (3), C. noduliferum (3), C. cf. pessimum (2), Zospeum 
Table 1 Individuals and sampling localities

\begin{tabular}{|c|c|c|c|c|c|}
\hline morphospecies & $\#$ & locality & geographical position & & EL \\
\hline Carychium O.F. Müller, 1774 & & & latitude & longitude & \\
\hline C. clappi & 1 & USA, Tennessee, La Follette & 36.332 & -83.998 & C1 \\
\hline \multirow[t]{3}{*}{ Hubricht, 1959} & 2 & USA, Tennessee, La Follette & 36.332 & -83.998 & C1 \\
\hline & 3 & USA, Tennessee, La Follette & 36.332 & -83.998 & $\mathrm{C} 1$ \\
\hline & 4 & USA, Tennessee, La Follette & 36.332 & -83.998 & $\mathrm{C} 1$ \\
\hline C. exiguum & 5 & USA, New York, Naples, Ontario County, Grimes Glen & 42.61591 & -77.41355 & C2 \\
\hline \multirow[t]{2}{*}{ Say, 1822} & 6 & USA, New York, Naples, Ontario County, Grimes Glen & 42.61591 & -77.41355 & $\mathrm{C} 2$ \\
\hline & 7 & USA, New York, Naples, Ontario County, Grimes Glen & 42.61591 & -77.41355 & $\mathrm{C} 2$ \\
\hline C. exile & 8 & USA, Indiana, Lawrence County, Williams Cave Sinkhole & 38.7555 & -86.59105 & C3 \\
\hline \multirow[t]{7}{*}{ H. C. Lea, 1842} & 9 & USA, Indiana, Lawrence County, Williams Cave Sinkhole & 38.7555 & -86.59105 & C3 \\
\hline & 10 & USA, Indiana, Lawrence County, Williams Cave Sinkhole & 38.7555 & -86.59105 & C3 \\
\hline & 11 & USA, New York, Portageville, Letchworth State Park & 42.57909 & -78.04945 & C3 \\
\hline & 12 & USA, New York, Portageville, Letchworth State Park & 42.57909 & -78.04945 & C3 \\
\hline & 13 & USA, New York, Watkins Glen & 42.375828 & -76.871115 & C3 \\
\hline & 14 & USA, New York, Watkins Glen & 42.375828 & -76.871115 & C3 \\
\hline & 15 & USA, New York, Watkins Glen & 42.375828 & -76.871115 & C3 \\
\hline C. exile mexicanum & 16 & USA, Georgia, Adairsville, Bartow County, Barnsley Gardens & 34.311233 & -84.9866 & $\mathrm{C} 1$ \\
\hline \multirow[t]{5}{*}{ Pilsbry, 1891} & 17 & USA, Georgia, Adairsville, Bartow County, Barnsley Gardens & 34.311233 & -84.9866 & $\mathrm{C} 1$ \\
\hline & 18 & USA, Alabama, Little River Mouth Park, Cherokee County & 34.312233 & -85.685733 & $\mathrm{C} 1$ \\
\hline & 19 & USA, Alabama, Little River Mouth Park, Cherokee County & 34.312233 & -85.685733 & $\mathrm{C} 1$ \\
\hline & 20 & USA, Illinois, Jackson County, Gorham & 37.6865 & -89.490667 & $\mathrm{C} 1$ \\
\hline & 21 & USA, Florida, Marianna & 30.810556 & -85.226667 & C4 \\
\hline C. floridanum & 22 & USA, Florida, Wakulla Springs & 30.23548 & -84.303087 & C5 \\
\hline \multirow[t]{4}{*}{ Clapp, 1918} & 23 & USA, Florida, Wakulla Springs & 30.23548 & -84.303087 & C5 \\
\hline & 24 & USA, Florida, Wakulla Springs & 30.23548 & -84.303087 & C5 \\
\hline & 25 & USA, Florida, Wakulla Springs & 30.23548 & -84.303087 & C5 \\
\hline & 26 & USA, Florida, Wakulla Springs & 30.23548 & -84.303087 & C5 \\
\hline C. cf. schlickumi & 27 & Greece, Epirus, loáninna Prov., Métsovo & 39.8213 & 21.1294 & C6 \\
\hline \multirow[t]{2}{*}{ Strauch, 1977} & 28 & Greece, Epirus, loáninna Prov., Métsovo & 39.8213 & 21.1294 & C6 \\
\hline & 29 & Greece, Epirus, loáninna Prov., Métsovo & 39.8213 & 21.1294 & C6 \\
\hline C. ibazoricum & 30 & Portugal, Azores, San Miguel, Sete Cidades & 37.847033 & -25.780217 & $\mathrm{C7}$ \\
\hline \multirow[t]{4}{*}{ Bank \& Gittenberger, 1985} & 31 & Portugal, Azores, San Miguel, Furnas & 37.770383 & -25.306583 & C7 \\
\hline & 32 & Portugal, Azores, San Miguel, Furnas & 37.770383 & -25.306583 & C7 \\
\hline & 33 & Portugal, Estremadura, near Sao Pedro de Moel & 39.774167 & -9.016667 & C7 \\
\hline & 34 & Portugal, Estremadura, near Sao Pedro de Moel & 39.774167 & -9.016667 & C7 \\
\hline C. lederi O. Boettger, 1880 & 35 & Iran, Mazandaran, Nowshahr, Kheiroudkanar forest & 36.605833 & 51.568333 & C8 \\
\hline C. mexicanum & 36 & USA, Georgia, Flovilla, Butts County, Indian Springs State Park & 33.242367 & -83.92035 & C9 \\
\hline \multirow[t]{4}{*}{ Pilsbry, 1891} & 37 & USA, Georgia, Flovilla, Butts County, Indian Springs State Park & 33.242367 & -83.92035 & C9 \\
\hline & 38 & USA, Georgia, Flovilla, Butts County, Indian Springs State Park & 33.242367 & -83.92035 & C9 \\
\hline & 39 & Belize, Maya Mountains, Bladen Nature Reserve & 16.557167 & -88.707833 & $\mathrm{C} 10$ \\
\hline & 40 & Belize, Maya Mountains, Bladen Nature Reserve & 16.557167 & -88.707833 & $\mathrm{C} 10$ \\
\hline C. mexicanum costaricanum & 41 & Costa Rica, Puntarenas, Santa Elena & 10.369833 & -84.804167 & $\mathrm{C} 11$ \\
\hline \multirow[t]{2}{*}{ Von Martens, 1898} & 42 & Costa Rica, Puntarenas, Monte Verde & 10.301333 & -84.790167 & $\mathrm{C} 11$ \\
\hline & 43 & Costa Rica, San José, San Gerardo de Dota & 9.5496 & -83.8032 & $\mathrm{C} 11$ \\
\hline
\end{tabular}


Table 1 Individuals and sampling localities (Continued)

\begin{tabular}{|c|c|c|c|c|c|}
\hline & 44 & Costa Rica, San José, San Gerardo de Dota & 9.5496 & -83.8032 & C11 \\
\hline & 45 & Costa Rica, San José, San Gerardo de Dota & 9.5496 & -83.8032 & C11 \\
\hline & 46 & $\begin{array}{l}\text { Panama, Chiriquí, Sendero el Retoño, Parque internacional la } \\
\text { Amistad }\end{array}$ & 8.8913 & -82.628611 & $\mathrm{C} 12$ \\
\hline & 47 & $\begin{array}{l}\text { Panama, Chiriquí, Sendero el Retoño, Parque internacional la } \\
\text { Amistad }\end{array}$ & 8.88815 & -82.620667 & $\mathrm{C} 12$ \\
\hline & 48 & $\begin{array}{l}\text { Panama, Chiriquí, Sendero el Retoño, Parque internacional la } \\
\text { Amistad }\end{array}$ & 8.88815 & -82.620667 & $\mathrm{C} 12$ \\
\hline & 49 & Panama, Chiriquí, near Boquete & 8.824767 & -82.495833 & C13 \\
\hline & 50 & Panama, Chiriquí, near Boquete & 8.824767 & -82.495833 & C13 \\
\hline & 51 & Panama, Chiriquí, near Boquete & 8.824767 & -82.495833 & $\mathrm{C} 13$ \\
\hline & 52 & Panama, Chiriquí, near Boquete & 8.824767 & -82.495833 & C13 \\
\hline C. minimum & 53 & Poland, Słubice & 52.3467 & 14.5806 & C14 \\
\hline \multirow[t]{2}{*}{ O.F. Müller, 1774} & 54 & Italy, Upper Adige, near Auer & 46.3385 & 11.3503 & C14 \\
\hline & 55 & Spain, Asturias, Gijón & 43.5204 & -5.6164 & C14 \\
\hline C. nannodes & 56 & USA, Tennessee, Overton County, Slit Cave & 36.456833 & -85.375067 & C15 \\
\hline \multirow[t]{2}{*}{ G.H. Clapp, 1905} & 57 & USA, Tennessee, Unicoi County, near Unaka Springs & 36.0986 & -82.4466 & C15 \\
\hline & 58 & Canada, Ontario, Crawford Lake & 43.4712 & -79.9464 & C15 \\
\hline C. nipponense & 59 & Japan, Honshu Is., Iwate, Ichinoseki, Geibikei & 38.9845 & 141.255667 & C16 \\
\hline Pilsbry \& Hirase, 1904 & 60 & Japan, Honshu Is., Fukushima, Urabandai & 37.687783 & 140.1205 & C16 \\
\hline C. noduliferum & 61 & Japan, Honshu Is., Iwate, Ichinoseki, Geibikei & 38.9845 & 141.255667 & C17 \\
\hline \multirow[t]{3}{*}{ Reinhardt, 1877} & 62 & Japan, Honshu Is., Fukushima, Urabandai & 37.687783 & 140.1205 & C17 \\
\hline & 63 & Japan, Honshu Is., Kanagawa, Yamakita, Oomatazawa & 35.423333 & 139.005 & C18 \\
\hline & 64 & Taiwan, Taichung County, Heping, Shei-Pa N.P., Huanshan & 24.37295 & 121.310567 & C19 \\
\hline C. occidentale & 65 & USA, Washington, Mason County & 47.3038 & -123.0918 & $\mathrm{C} 20$ \\
\hline \multirow[t]{4}{*}{ Pilsbry, 1891} & 66 & USA, Washington, Mason County & 47.3038 & -123.0918 & $\mathrm{C} 20$ \\
\hline & 67 & USA, Washington, Mason County & 47.3038 & -123.0918 & $\mathrm{C} 20$ \\
\hline & 68 & USA, Washington, Mason County & 47.3038 & -123.0918 & $\mathrm{C} 20$ \\
\hline & 69 & USA, Washington, Mason County & 47.3038 & -123.0918 & $\mathrm{C} 20$ \\
\hline C. cf. pessimum & 70 & Russia, Vladivostok, Promorsky Kray & 43.193417 & 132.0511 & $\mathrm{C} 21$ \\
\hline \multirow[t]{5}{*}{ Pilsbry, 1902} & 71 & Russia, Vladivostok, Promorsky Kray & 43.193417 & 132.0511 & C21 \\
\hline & 72 & Russia, Vladivostok, Promorsky Kray & 43.193417 & 132.0511 & C21 \\
\hline & 73 & Russia, Vladivostok, Promorsky Kray & 43.193417 & 132.0511 & $\mathrm{C} 21$ \\
\hline & 74 & Russia, Vladivostok, Promorsky Kray & 43.193417 & 132.0511 & $\mathrm{C} 21$ \\
\hline & 75 & Japan, Honshu Is., Iwate, Sarusawa & 39.021167 & 141.292833 & $\mathrm{C} 22$ \\
\hline C. stygium & 76 & USA, Kentucky, Hart County, Horse Cave (Hidden River Cave) & 37.174167 & -85.903833 & $\mathrm{C} 1$ \\
\hline \multirow[t]{3}{*}{ Call, 1897} & 77 & USA, Kentucky, Hart County, Horse Cave (Hidden River Cave) & 37.174167 & -85.903833 & $\mathrm{C} 1$ \\
\hline & 78 & USA, Tennessee, Slit Cave (cave entrance) & 36.456833 & -85.375067 & $\mathrm{C} 1$ \\
\hline & 79 & USA, Tennessee, Slit Cave (cave entrance) & 36.456833 & -85.375067 & $\mathrm{C} 1$ \\
\hline C. tridentatum & 80 & Switzerland, St. Gallen, St. Gallen & 47.36 & 9.14 & $\mathrm{C} 23$ \\
\hline \multirow[t]{2}{*}{ (Risso, 1826) } & 81 & Italy, Upper Adige, near Auer & 46.3385 & 11.3503 & $\mathrm{C} 23$ \\
\hline & 82 & France, Britanny, near Lopreden & 48.596667 & -3.97 & $\mathrm{C} 23$ \\
\hline \multirow[t]{2}{*}{ Carychium sp. 1} & 83 & $\begin{array}{l}\text { Bulgaria, Mostovo Village, entrance Gargina Dupka Cave } \\
\text { (Rhodopi Mnt.) }\end{array}$ & 41.850667 & 24.926183 & $C 23$ \\
\hline & 84 & $\begin{array}{l}\text { Bulgaria, Mostovo Village, entrance Gargina Dupka Cave } \\
\text { (Rhodopi Mnt.) }\end{array}$ & 41.850667 & 24.926183 & $C 23$ \\
\hline
\end{tabular}


Table 1 Individuals and sampling localities (Continued)

\begin{tabular}{|c|c|c|c|}
\hline & 85 & Italy, Lombardy, Lago Maggiore, Laveno-Mombello & 45.90718 \\
\hline & 86 & Italy, Lombardy, Lago d'Iseo, Vigolo & 45.7367 \\
\hline & 87 & Romania, Bacâia & 46.0249 \\
\hline & 88 & Georgia, Kakheti Province, Lagodekhi Nature Reserve & 41.88 \\
\hline & 89 & Georgia, Kakheti Province, Lagodekhi Nature Reserve & 41.88 \\
\hline \multirow[t]{5}{*}{ Carychium sp. 2} & 90 & China, Yunnan, Zhongdian County, Shangri-La & 27.501017 \\
\hline & 91 & China, Yunnan, Zhongdian County, Shangri-La & 27.501017 \\
\hline & 92 & China, Yunnan, Zhongdian County, Shangri-La & 27.501017 \\
\hline & 93 & China, Yunnan, Zhongdian County, Shangri-La & 27.501017 \\
\hline & 94 & China, Yunnan, Zhongdian County, Shangri-La & 27.501017 \\
\hline \multirow[t]{3}{*}{ Carychium sp. 3} & 95 & China, North Sichuan, Songpan County, Huanglong & 32.7373 \\
\hline & 96 & China, North Sichuan, Songpan County, Huanglong & 32.7373 \\
\hline & 97 & China, North Sichuan, Songpan County, Huanglong & 32.7373 \\
\hline Zospeum Bourguignat, 1856 & & & cave name \\
\hline Z. alpestre kupitzense & 98 & Slovenia, Kamnik-Savinja Alps, Solčava & Ložekarjeva zijalka \\
\hline A. Stummer, 1984 & 99 & Slovenia, Kamnik-Savinja Alps, Solčava & Ložekarjeva zijalka \\
\hline $\begin{array}{l}\text { Z. cf. biscaiense Gómez \& Prieto, } \\
1983\end{array}$ & 100 & Spain, Garaimendi, Yurre & Cueva de Otxas* \\
\hline Z. exiguum & 101 & Slovenia, Cerknica, Lož & Križna jama* \\
\hline \multirow[t]{4}{*}{ Kusčer, 1932} & 102 & Slovenia, Cerknica, Lož & Križna jama* \\
\hline & 103 & Slovenia, Cerknica, Lož & Križna jama* \\
\hline & 104 & Slovenia, Cerknica, Lož & Križna jama* \\
\hline & 105 & Slovenia, Cerknica, Lož & Križna jama* \\
\hline Z. frauenfeldi & 106 & Slovenia, Dobrepolje, Podpeč & Podpeška jama* \\
\hline \multirow[t]{4}{*}{ (Freyer, 1855) } & 107 & Slovenia, Dobrepolje, Podpeč & Podpeška jama* \\
\hline & 108 & Slovenia, Dobrepolje, Podpeč & Podpeška jama* \\
\hline & 109 & Slovenia, Dobrepolje, Podpeč & Podpeška jama* \\
\hline & 110 & Slovenia, Dobrepolje, Podpeč & Podpeška jama* \\
\hline Z. isselianum & 111 & Slovenia, Kamnik, Kamniška Bistrica & Jama pod Farjevim plazom \\
\hline \multirow[t]{7}{*}{ Pollonera, 1887} & 112 & Slovenia, Kobarid*, Robič & Turjeva jama \\
\hline & 113 & Slovenia, Kamnik-Savinja Alps, Šmihel nad Mozirjem & Konečka zijalka \\
\hline & 114 & Slovenia, Kamnik-Savinja Alps, Šmihel nad Mozirjem & Konečka zijalka \\
\hline & 115 & Croatia, Kordun, Karlovac, Krnjak, Brebornica Mts. & Jopićeva špilja \\
\hline & 116 & Croatia, Kordun, Karlovac, Krnjak, Brebornica Mts. & Jopićeva špilja \\
\hline & 117 & Croatia, Kordun, Karlovac, Krnjak, Brebornica Mts. & Jopićeva špilja \\
\hline & 118 & Croatia, Kordun, Karlovac, Krnjak, Brebornica Mts. & Jopićeva špilja \\
\hline Z. obesum & 119 & Slovenia, Gradiček, Krška vas & Krška jama* \\
\hline \multirow[t]{2}{*}{ (Frauenfeld, 1854) } & 120 & Slovenia, Gradiček, Krška vas & Krška jama* \\
\hline & 121 & Slovenia, Gradiček, Krška vas & Krška jama* \\
\hline Z. pretneri Bole, 1960 & 122 & Croatia, Gračac, Kesići & Donja Cerovačka špilja* \\
\hline Z. spelaeum schmidti & 123 & Slovenia, Veliki Otok, Postojna & Betalov Spodmol \\
\hline \multirow[t]{4}{*}{ (Frauenfeld, 1854) } & 124 & Slovenia, Loka pri Mengšu & Jama 1 pri Jabljah \\
\hline & 125 & Slovenia, Loka pri Mengšu & Jama 1 pri Jabljah \\
\hline & 126 & Slovenia, Loka pri Mengšu & Jama 1 pri Jabljah \\
\hline & 127 & Slovenia, Loka pri Mengšu & Jama 1 pri Jabljah \\
\hline
\end{tabular}

$\begin{array}{ll}8.6625 & C 23 \\ 10.0025 & C 23 \\ 23.1734 & C 23 \\ 46.31 & C 23 \\ 46.31 & C 23 \\ 100.033833 & C 24 \\ 100.033833 & C 24 \\ 100.033833 & C 24 \\ 100.033833 & C 24 \\ 100.033833 & C 24 \\ 103.824383 & C 25 \\ 103.824383 & C 25 \\ 103.824383 & C 25\end{array}$

Z1

Z1

Z2

Z3

$\mathrm{Z3}$

$\mathrm{Z3}$

$\mathrm{Z3}$ 
Table 1 Individuals and sampling localities (Continued)

\begin{tabular}{|c|c|c|c|c|}
\hline & 128 & Slovenia, Loka pri Mengšu & Jama 1 pri Jabljah & $\mathrm{Z12}$ \\
\hline & 129 & Slovenia, Krim Region, Gornji Ig & Velika Pasica* & Z11 \\
\hline & 130 & Slovenia, Krim Region, Gornji Ig & Velika Pasica* & Z11 \\
\hline & 131 & Italy, Trieste, near Gabrovizza San Primo & Grotte d'Ercole & Z11 \\
\hline & 132 & Italy, Trieste, near Gabrovizza San Primo & Grotte d'Ercole & Z11 \\
\hline & 133 & Italy, Trieste, near Basovizza & Grotte Bac & Z11 \\
\hline & 134 & Italy, Trieste, near Basovizza & Grotte Bac & Z11 \\
\hline & 135 & Italy, Trieste, near Samatorza & Grotte Azzurra & Z11 \\
\hline Z. suarezi & 136 & Spain, Cantabria, Novales, La Busta & Cueva del Linar & Z13 \\
\hline \multirow[t]{9}{*}{ Gittenberger, 1980} & 137 & Spain, Cantabria, Novales, La Busta & Cueva del Linar & Z13 \\
\hline & 138 & Spain, Cantabria, Novales, La Busta & Cueva del Linar & Z13 \\
\hline & 139 & Spain, Cantabria, Novales, La Busta & Cueva del Linar & $\mathrm{Z13}$ \\
\hline & 140 & Spain, Asturias, Inguanzo & $\begin{array}{l}\text { Cueva del Bosque/Cueva } \\
\text { Inguanzo* }\end{array}$ & Z14 \\
\hline & 141 & Spain, Asturias, Inguanzo & $\begin{array}{l}\text { Cueva del Bosque/Cueva } \\
\text { Inguanzo* }\end{array}$ & Z14 \\
\hline & 142 & Spain, Bizkaia, San Pedro de Galdames, Barranco de Aranaga & Cueva de los Cuervos & Z15 \\
\hline & 143 & Spain, Bizkaia, San Pedro de Galdames, Barranco de Aranaga & Cueva de los Cuervos & Z15 \\
\hline & 144 & Spain, Bizkaia, San Pedro de Galdames, Barranco de Aranaga & Cueva de los Cuervos & Z15 \\
\hline & 145 & Spain, Castilla y León, Monte Santiago & Cueva de Las Paúles & Z16 \\
\hline Z. subobesum & 146 & Croatia, Ogulin, Tounj & Tounjčica* & Z8 \\
\hline \multirow[t]{2}{*}{ Bole, 1974} & 147 & Croatia, Ogulin, Tounj & Tounjčica* & Z8 \\
\hline & 148 & Croatia, Ogulin, Tounj & Tounjčica* & Z8 \\
\hline \multirow[t]{12}{*}{ Zospeum sp. 1} & 149 & Spain, Bizkaia, Guipúzcoa Mts., Valle de Araotz & Cueva de Ermita de Sandaili & $\mathrm{Z17}$ \\
\hline & 150 & Spain, Bizkaia, Guipúzcoa Mts., Valle de Araotz & Cueva de Ermita de Sandaili & Z17 \\
\hline & 151 & Spain, Bizkaia, Guipúzcoa Mts., Valle de Araotz & Cueva de Ermita de Sandaili & Z17 \\
\hline & 152 & Spain, Garaimendi, Yurre & Cueva de Otxas & $\mathrm{Z17}$ \\
\hline & 153 & Spain, Garaimendi, Yurre & Cueva de Otxas & $\mathrm{Z17}$ \\
\hline & 154 & Spain, Garaimendi, Yurre & Cueva de Otxas & $\mathrm{Z17}$ \\
\hline & 155 & Spain, Garaimendi, Yurre & Cueva de Otxas & $\mathrm{Z17}$ \\
\hline & 156 & Spain, Garaimendi, Yurre & Cueva de Otxas & Z17 \\
\hline & 157 & Spain, Bizkaia, Manaria, Urkuleta Valley & Cueva Silibranka II & $\mathrm{Z17}$ \\
\hline & 158 & Spain, Bizkaia, Manaria, Urkuleta Valley & Cueva Silibranka II & $\mathrm{Z17}$ \\
\hline & 159 & Spain, Bizkaia, Manaria, Urkuleta Valley & Cueva Silibranka II & $\mathrm{Z17}$ \\
\hline & 160 & Spain, Bizkaia, Dima, Indusi & Cueva del Cráneo & $\mathrm{Z17}$ \\
\hline \multirow[t]{3}{*}{ Zospeum sp. 2} & 161 & Spain, Castilla y León, Monte Santiago & Cueva de Las Paúles & Z18 \\
\hline & 162 & Spain, Castilla y León, Monte Santiago & Cueva de Las Paúles & Z18 \\
\hline & 163 & Spain, Castilla y León, Monte Santiago & Cueva de Las Paúles & Z18 \\
\hline \multicolumn{5}{|l|}{ Outgroup taxa } \\
\hline Pythiidae, Laemodonta cubensis & 164 & $\begin{array}{l}\text { Bermuda, Hamilton Parish, Walsingham Pond, outside Cliff } \\
\text { Cave }\end{array}$ & 32.34773 & -64.70965 \\
\hline $\begin{array}{l}\text { Melampodidae, Microtralia } \\
\text { occidentalis }\end{array}$ & 165 & Bermuda, St. George Parish, St. George Island, Lover's Lake & 32.36750 & -64.70990 \\
\hline $\begin{array}{l}\text { Veronicellidae, Veronicella } \\
\text { cubensis }\end{array}$ & 166 & $\begin{array}{l}\text { Bermuda, Devonshire Parish, Winfried Gibbons Nature } \\
\text { Reserve, South Road }\end{array}$ & 32.30230 & -64.74450 \\
\hline
\end{tabular}

Data on the morphological identification, taxonomic first description, specimen number (\#), sampling locality and evolutionary lineage (EL) are provided. Type locality populations or localities referred to in the phenotype descriptions of Zospeum morphospecies are marked by an asterisk. 

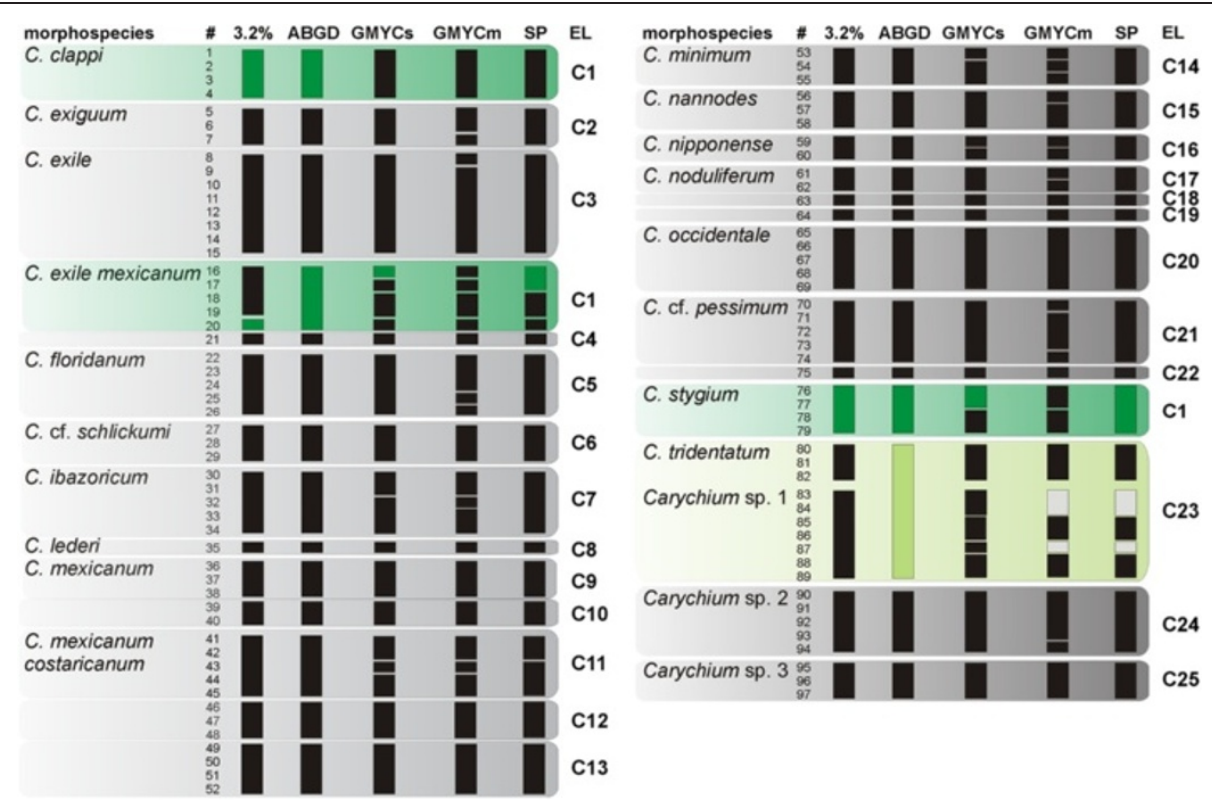

Figure 3 Molecular delimitation of Carychium evolutionary lineages. Results of the five genetic delimitation approaches are indicated. For Carychium, 97 specimens (\#) comprising 18 morphospecies and three undescribed taxa are analysed. A conservative strategy identified 25 evolutionary lineages (EL; C1-C25). Specimens clusters identified under each single delimitation method (3.2\%, ABGD, GMYCs, GMYCm and SP) are indicated by black boxes. Grey boxes refer to clustered specimens within a single morphospecies (e.g. SP, \# '83' + '84' + '87'), colored boxes to specimens between different morphospecies (e.g. SP, \# '16' + '17' + '76-79').

isselianum (3), Z. spelaeum schmidti (2) and Z. suarezi (4). Hence, we uncovered at least 20 ELs that could not clearly be distinguished with the initial morphospecies hypotheses (i.e. 47\% of all ELs). For Zospeum isselianum, Z. spelaeum schmidti, Z. suarezi, Z. subobesum and Carychium mexicanum costaricanum, our analysis of topotypic populations enabled us to link a single EL to the initial morphospecies hypothesis (Tables 1 and 2). The three morphospecies, Zospeum isselianum, Z. spelaeum schmidti and $Z$. suarezi were found over a large geographical area and possessed moderately variable shell phenotypes, two characteristics that make them prime candidates for taxonomic lumping. Specimens of $C$. exile mexicanum, C. clappi and C. stygium shared closely related barcodes and consequently, were treated as a single taxon (C1). The European Carychium sp. 1 (C23)

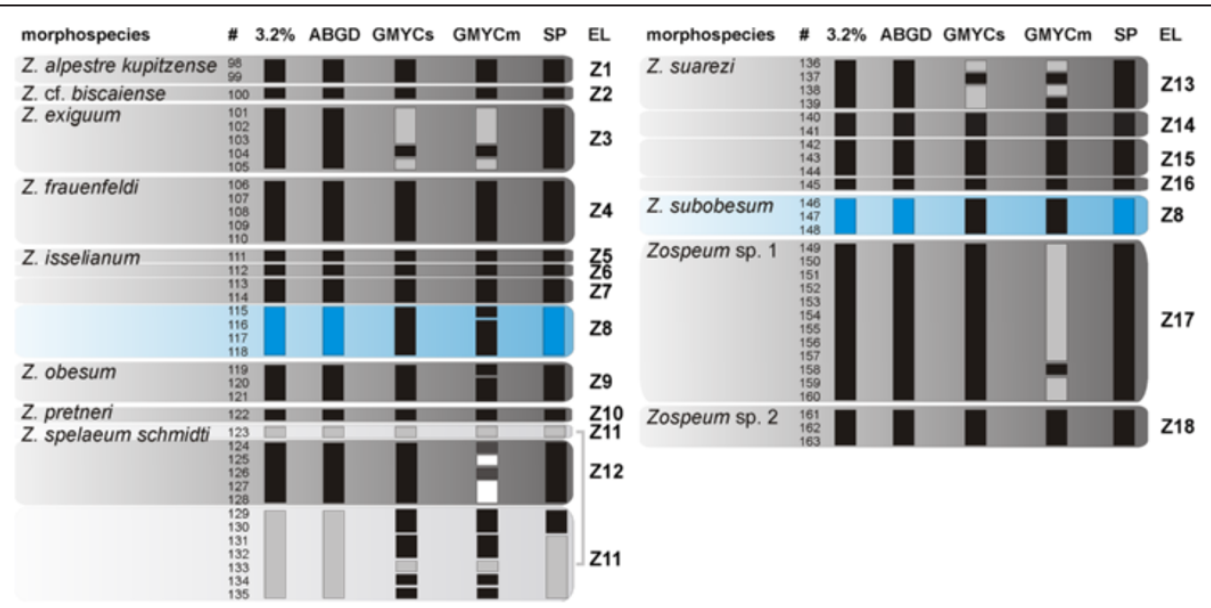

Figure 4 Molecular delimitation of Zospeum evolutionary lineages. Results of the five genetic delimitation approaches are indicated. For Zospeum, 66 specimens (\#) comprising 10 morphospecies and two undescribed taxa are analysed. A conservative strategy identified 18 evolutionary lineages (EL; Z1-Z18). Specimens clusters identified under each single delimitation method (3.2\%, ABGD, GMYCs, GMYCm and SP) are indicated by black boxes. Grey boxes refer to clustered specimens within a single morphospecies (e.g. 3.2\%, \#'123' + '129-135'), colored boxes to specimens between different morphospecies (e.g. 3.2\%, \# '115-118' + '146-148'). 
Table 2 Integrative identification of evolutionary lineages in Carychiidae

\begin{tabular}{|c|c|}
\hline EL & cross-validation with MA \\
\hline$\overline{C 1}$ & $\begin{array}{l}\text { includes C. clappi, some specimens of C. exile mexicanum and } \\
\text { C. stygium }\end{array}$ \\
\hline $\mathrm{C2}$ & matches C. exiguum \\
\hline C3 & matches C. exile \\
\hline C4 & lumped with specimens from $\mathrm{Cl}$ as $\mathrm{C}$. exile mexicanum \\
\hline C5 & matches C. floridanum \\
\hline C6 & matches C. cf. schlickumi \\
\hline C7 & matches C. ibazoricum \\
\hline C8 & matches C. lederi \\
\hline C9 & lumped with $\mathrm{C} 10$ as $C$. mexicanum \\
\hline C10 & lumped with C9 as C. mexicanum \\
\hline C11 & $\begin{array}{l}\text { regarded as } C \text {. costaricanum; lumped with } \mathrm{C} 12+\mathrm{C} 13 \text { as } C \text {. } \\
\text { mexicanum costaricanum }\end{array}$ \\
\hline $\mathrm{C} 12$ & lumped with $\mathrm{C} 11+\mathrm{C} 13$ as $\mathrm{C}$. mexicanum costaricanum \\
\hline $\mathrm{C} 13$ & lumped with $\mathrm{C} 11+\mathrm{C} 12$ as $\mathrm{C}$. mexicanum costaricanum \\
\hline C14 & matches C. minimum \\
\hline C15 & matches $C$. nannodes \\
\hline C16 & matches C. nipponense \\
\hline $\mathrm{C} 17$ & lumped with C18 + C19 as C. noduliferum \\
\hline C18 & lumped with C17 + C19 as C. noduliferum \\
\hline C19 & lumped with $\mathrm{C} 17+\mathrm{C} 18$ as C. noduliferum \\
\hline $\mathrm{C} 20$ & matches $C$. occidentale \\
\hline C21 & lumped with C22 as C. cf. pessimum \\
\hline $\mathrm{C} 22$ & lumped with C21 as C. cf. pessimum \\
\hline $\mathrm{C} 23$ & includes C. tridentatum and Carychium sp. 1 \\
\hline $\mathrm{C} 24$ & matches Carychium sp. 2 \\
\hline $\mathrm{C} 25$ & matches Carychium sp. 3 \\
\hline $\mathrm{Z1}$ & matches $Z$. alpestre kupitzense \\
\hline $\mathrm{Z2}$ & matches Z. cf. biscaiense \\
\hline Z3 & matches Z. exiguum \\
\hline Z4 & matches $Z$. frauenfeldi \\
\hline Z5 & lumped with Z6 + Z7 as Z. isselianum \\
\hline Z6 & regarded as Z. isselianum; lumped with Z5 + Z7 as Z. isselianum \\
\hline $\mathrm{Z7}$ & lumped with Z5 + Z6 as Z. isselianum \\
\hline Z8 & $\begin{array}{l}\text { matches } Z \text {. subobesum; specimens } 146-148 \text { identified as } Z \text {. } \\
\text { isselianum }\end{array}$ \\
\hline Z9 & matches Z. obesum \\
\hline Z10 & matches Z. pretneri \\
\hline $\mathrm{Z11}$ & $\begin{array}{l}\text { regarded as Z. spelaeum schmidti; lumped with Z12 as Z. spelaeum } \\
\text { schmidti }\end{array}$ \\
\hline Z12 & lumped with Z11 as Z. spelaeum schmidti \\
\hline $\mathrm{Z13}$ & lumped with Z14, Z15 + Z16 as Z. suarezi \\
\hline Z14 & regarded as Z. suarezi; lumped with Z13, Z15 + Z16 as Z. suarezi \\
\hline Z15 & lumped with Z13, Z14 + Z17 as Z. suarezi \\
\hline Z16 & lumped with Z13, Z14 + Z15 as Z. suarezi \\
\hline
\end{tabular}

Table 2 Integrative identification of evolutionary lineages in Carychiidae (Continued)

Z17 matches Zospeum sp. 1

Z18 matches Zospeum sp. 2

Overview of cross-validated evolutionary lineages (EL) and initial morphospecies assignments (MA). 'matches' = direct match between EL and initial MA; 'lumped' = more than one EL in initial MA; 'includes' = EL includes more than one morphologically delineated taxon; 'regarded $\mathrm{as}^{\prime}$ ' = used for a 'lumped' EL in case type locality populations have been analyzed.

needs further consideration since results of the barcoding approach and phylogenetic reconstruction were not congruent. Thus, two ELs (C1 and C23) included more than one morphospecies each.

\section{Phylogenetic tree hypothesis}

Phylogenetic relationships of 38 ELs based on 1210 bp of nuclear (H3) and mitochondrial sequence data (COI and $16 \mathrm{~S}$ ) were estimated with three different phylogenetic inference methods. Maximum Likelihood (ML), Maximum Composite Likelihood (MCL) and Bayesian inference (BI) yielded mainly congruent results (Figure 5). Lineage assignments correspond to the identification scheme for ELs described in the previous chapter however, with the following exceptions: morphologically unrecognized ELs, for which topotypic populations of the same morphospecies were analysed, were marked with 'sp. cf.' and the morphospecies name (e.g. Z16, Z. sp. cf. suarezi). The EL of the same morphospecies, which included specimens from the type locality or from localities used for the phenotype description, was named after the morphospecies hypothesis (e.g. Z14, Z. suarezi from Cueva Inguanzo referred to in the first description [31]). Due to the molecular distinctiveness of C. costaricanum (C11) from its type locality [32], we address this taxon at the species level.

The morphologically and ecologically defined designation into Carychium and Zospeum was supported by molecular data (MCL: 100; PP: 1.00; ML $\geq 97$ ). All analysed mitochondrial ELs (C1-25 and Z1-18, Figure 5) were monophyletic after incorporation of ncDNA with the exception of Carychium sp. 1 (C23). However, sister relationship between lineages were not resolved entirely. Only the relationship of one individual of Carychium sp. 1 to C. ibazoricum (C7) was highly supported (97; $1.00 ; 100)$. Another cluster formed by two lineages of Carychium sp. 1 and C. tridentatum was only weakly supported (82; 0.95; -).

Except for C. nannodes, the North + Central $(\mathrm{N}+\mathrm{C})$ American taxa can be traced back to one most recent common ancestral lineage $(93 ; 1.00 ; 79)$. The only Carychium taxon with a distribution along the West Coast of North America, C. occidentale forms the sister group to all other taxa in North and Central America 


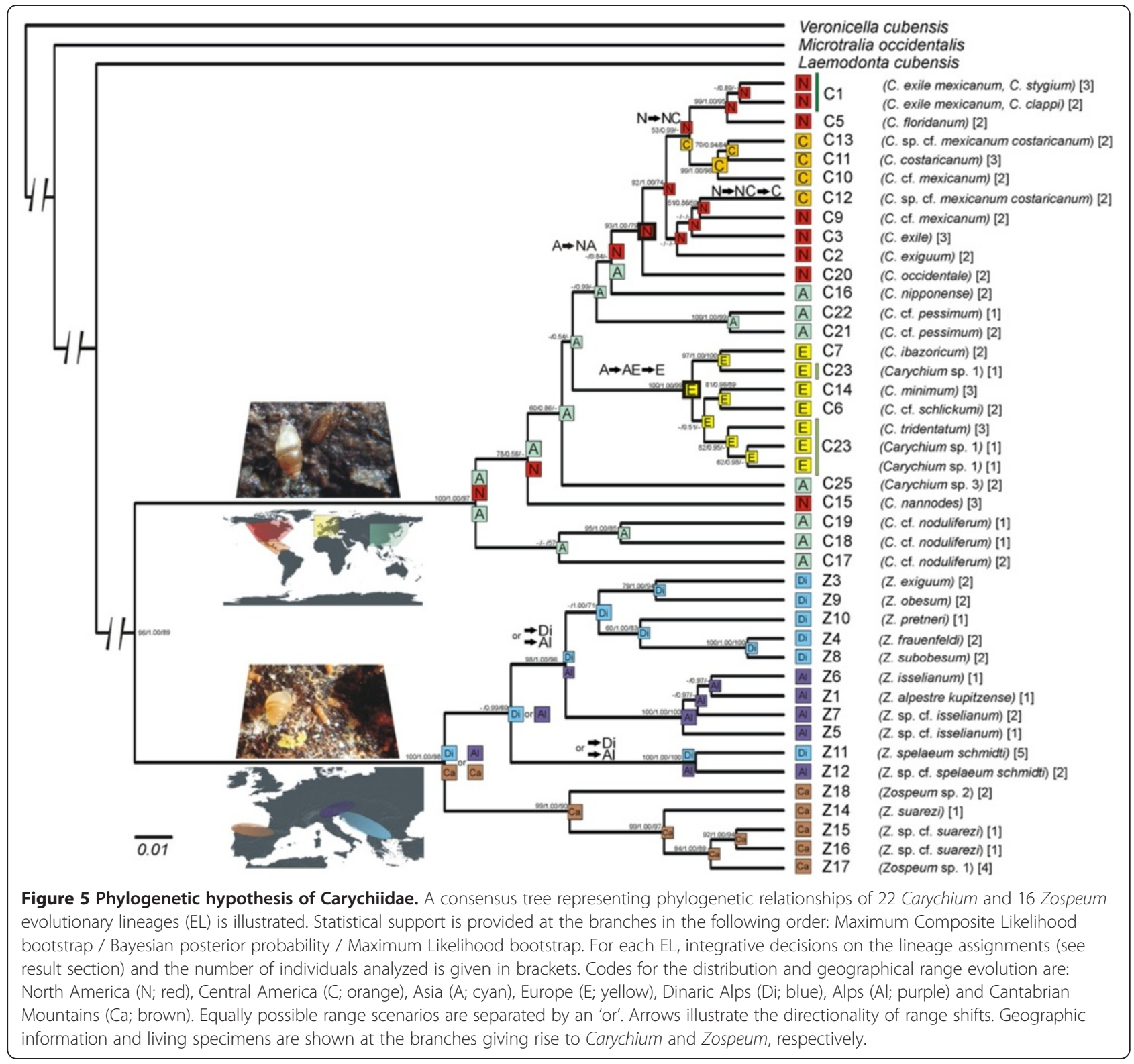

(92; 1.00; 79). Extant European Carychium have descended from a single lineage (100; $1.00 ; 99)$.

Well resolved divergence events for ELs of Carychium comprised: i) a clustering of $\mathrm{C} 1+\mathrm{C} 5$, including the morphospecies $C$. exile mexicanum, C. stygium, C. clappi and C. floridanum $(99 ; 1.00 ; 95)$, ii) a clade formed by three C-American lineages $\mathrm{C} 10+\mathrm{C} 11+\mathrm{C} 13$ and the morphospecies $C$. cf. mexicanum, C. costaricanum and C. cf. mexicanum costaricanum $(99 ; 1.00 ; 96)$ and iii) the sister group relationship of $C$. minimum (C14) and $C$. cf. schlickumi (C6) $(81 ; 0.96 ; 89)$.

Support values for diversification events within Zospeum were high. Zospeum from the Cantabrian Mountains were monophyletic $(99 ; 1.00 ; 90)$. A sister group relationship between Zospeum sp. 2 (Z18) and a clade comprising the morphospecies Z. suarezi and Zospeum sp. 1 (Z17) was revealed $(99 ; 1.00 ; 97)$. Within this clade, three distinct ELs form the morphospecies Z. suarezi (Z14-Z16), which was paraphyletic with respect to Zospeum sp. 1 (94; 1.00; 89). The widely distributed morphospecies $Z$. spelaeum schmidti was monophyletic but contained two deeply separated ELs $(100 ; 1.00 ; 100)$. Monophyly between the Alpine Z. isselianum (Z5-Z7) and Z. alpestre kupitzense (Z1) was strongly supported $(100 ; 1.00 ; 100)$. The relationship between the Dinaric morphospecies $Z$. exiguum, Z. obesum, Z. pretneri, Z. frauenfeldi and Z. subobesum received only partial support $(-; 1.00 ; 71)$. Sister group relationships between the Dinaric $Z$. frauenfeldi $(\mathrm{Z} 4)$ and Z. subobesum $(Z 8)(100 ; 1.00 ; 100)$ and between $Z$. exiguum $(\mathrm{Z3})$ and $Z$. obesum $(\mathrm{Z9})(79 ; 1.00 ; 94)$ were well 
resolved. Remarkably, the Dinaric $Z$. isselianum (specimens 115-118, Z8, see Figure 4) did not cluster with other Alpine Z. isselianum lineages (Z5-Z7) but fell within the Dinaric clade. Dinaric $Z$. isselianum were probably misidentified. They clustered with Z. subobesum (Z8) for which topotypic specimens have been analyzed (Figures 4 and 5, Tables 1 and 2).

\section{Biogeographical reconstruction}

Geographical range evolution of Carychiidae was reconstructed to evaluate geographical transitions and the presence or absence of geographically monophyletic clades. Results are shown only for the model where taxa inhabit a maximum of two regions (continents or mountain ranges). Differences to alternative models, where the maximum range was allowed to encompass all ranges (3 or 4 ), were largely restricted to basal nodes. However, in some cases these scenarios resulted in extremely wide ancestral ranges which seems biologically unreasonable. Generally, geographical proximally distributed taxa were closely related. Only few colonization events were discovered. The range reconstruction of the most likely (conservative) scenario for the root node of Carychium revealed an 'Asian' (A) or 'Asian + North American' $(\mathrm{A}+\mathrm{N})$ origin (Figure 5).

The oldest diversification events within Carychium are characterized by relatively short branches with low statistical support, giving rise mostly to deep Asian lineages. Central America could have been colonized by more than one lineage. The European branch originated out of a long separately evolving lineage. We further tested two alternative tree hypotheses for Carychium in a model selection framework: i) constrained monophyletic Asian Carychium and ii) constrained monophyletic American Carychium (see Additional file 1). Both constraints received higher support than the unconstrained phylogenetic hypothesis. Monophyletic Asian and/or American lineages should not be ruled out (Table 3).

The geographic origin of Zospeum could not be unambiguously resolved (Figure 5). Our reconstructions equally supported an ancestral distribution in the 'Cantabrian Mountains + Alps' or 'Cantabrian Mountains + Dinaric Alps'. In comparison to Carychium, Zospeum arrived much earlier in Europe. Only two colonization events were discovered: Both lineages of $Z$. spelaeum schmidti were geographically restricted to the Alps (Z12) and the Dinaric Alps (Z11), respectively. Moreover, the sister clade (comprised of all other Dinaric and Alpine taxa) demonstrated a similar pattern with separate colonization of the Alps or Dinaric Alps; depending upon the ancestral state. We tested our phylogenetic hypothesis against two constrained hypotheses for Zospeum: i) monophyletic Dinaric Zospeum and ii) monophyletic Alpine Zospeum. Both scenarios
Table 3 Model selection results of alternative phylogenetic hypothesis testing

\begin{tabular}{lccc}
\hline hypothesis & DAICM & In $_{\text {BF }}$ PS & In BF $_{\mathbf{S S}}$ \\
\hline monophyletic American Carychium & 0.00 & 0.00 & 0.00 \\
monophyletic Asian Carychium & -14.07 & 17.24 & 17.66 \\
unconstrained phylogeny & -18.96 & 44.86 & 45.14 \\
monophyletic Alpine Zospeum & -157.41 & 85.25 & 85.81 \\
monophyletic Dinaric Zospeum & -345.81 & 191.58 & 190.53 \\
\hline
\end{tabular}

Results of the model selection approach to test the monophyly of geographically closely distributed taxa. Hypotheses are ranked according to model fit. $\mathrm{AICM}=$ modified Akaike Information Criterion; $\mathrm{BF}_{\mathrm{PS}}=$ Bayes Factor based on path simulation sampling; $\mathrm{BF}_{\mathrm{SS}}=$ Bayes Factor based on stepping stone sampling. $\mathrm{A}$ $\triangle \mathrm{AICM}>7$ and $\ln \mathrm{BF}>2.3$ are seen as strong model support.

received considerably lower support than the unconstrained hypothesis (Table 3).

\section{Temporal dynamics of lineage diversification}

By fitting different models of diversification using a maximum likelihood approach, temporal dynamics of the diversification of lineages, such as rate shifts due to historic climatic or tectonic changes, were investigated. To account for uncertainties in species delimitation, the analyses were performed on each of the five trees produced by the genetic delimitation approaches (threshold, ABGD, SP, GMYCs and GMYCm). A constant rate model of diversification was preferred for the GMYCm tree (Figure 6, Table 4), whereas a rate-variable model (yule2rate) provided a better fit for all other trees (but not significantly in case of the GMYCs tree). A two-rate pure-birth model best explained the data for the threshold, ABGD and SP trees (Table 4) with a recent decrease (relative shift time approx. $-0.01)$ of the speciation rate.

\section{Bioclimatic niche differentiation}

Bioclimatic niche modeling was performed to study niche differences between two well supported Carychium clades and to identify potential climatic factors responsible for lineage persistence and diversification. Maxent models based on occurrence data of European and North + Central American Carychium behaved realistically and were statistically well supported (AUC Europe: $0.769 \pm 0.033$;

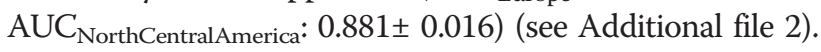
Bioclimatic niche models for native Carychium taxa in America and in Europe, respectively, generally predicted wide areas of suitable habitat (see Additional file 2A, B). The American model was characterized by a sharp longitudinal transition from suitable habitats in the East to unsuitable conditions in the West. Visual inspection of the geographical distribution of all 19 bioclimatic variables throughout this region identified diurnal range (bio2) to best explain the observed pattern (see Additional file 3). Modeling results for Europe highlighted a continuous region of high habitat suitability, stretching from the 

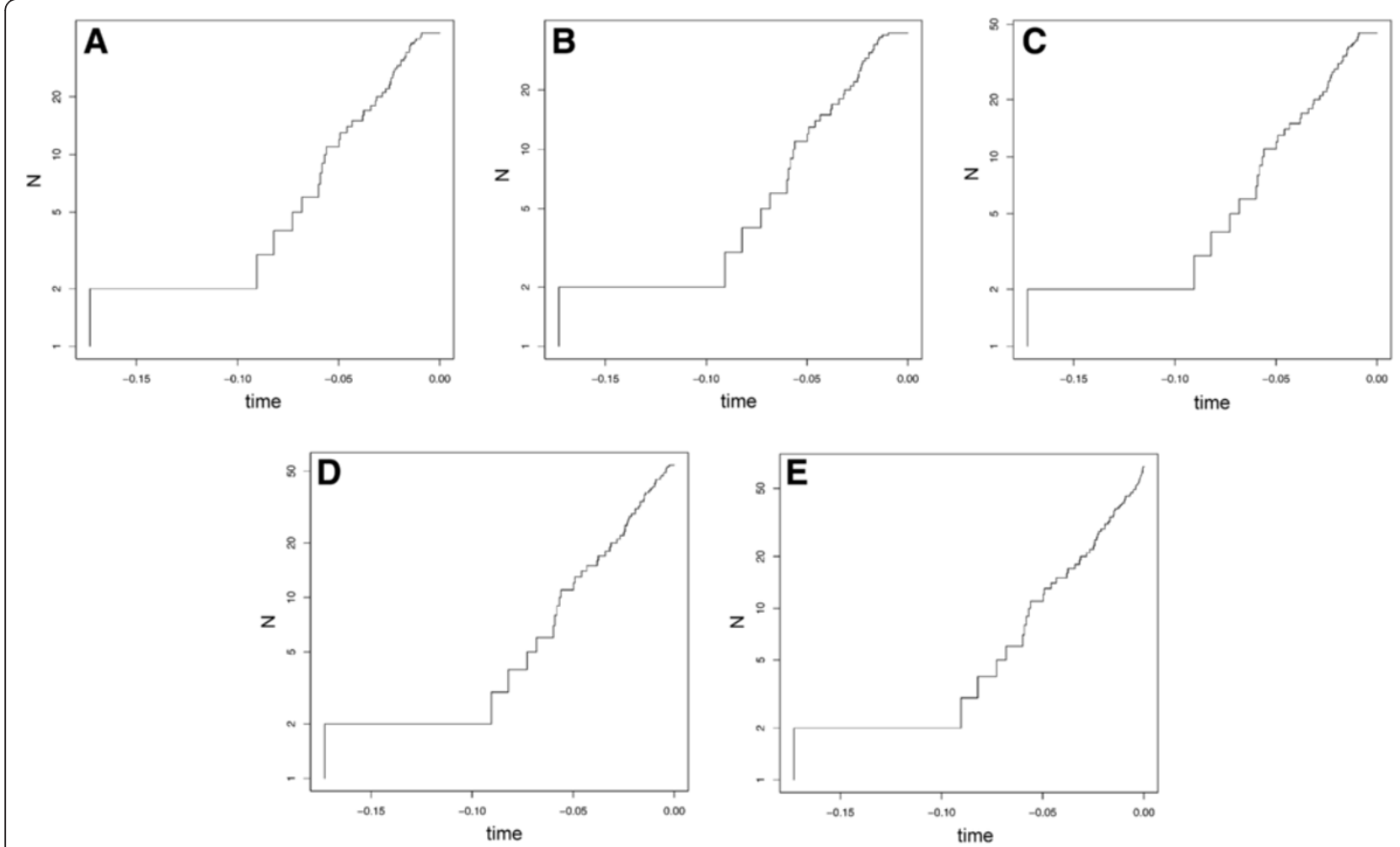

Figure 6 Lineage through time plots (LTT-plot). The diversification of lineages ( $y$-axis; cumulative number of lineages) through time ( $x$-axis; relative time estimates) is plotted in five different ways according to the delimitation of evolutionary lineages: A: $3.2 \%$ threshold value partition. B: Automatic Barcoding Gap Detection (ABGD) partition. C: Statistical Parsimony (SP) partition. D: General Mixed Yule-Coalescent single (GMYCs) partition. E: General Mixed Yule-Coalescent multiple (GMYCm) partition.

Mediterranean Sea to Northern Scandinavia and from the Atlantic Coast to the Black Sea.

Compared to the niche model of the native clade in Europe, the projected model for America suspected European Carychium to inhabit regions at lower and higher latitude (see Additional file 2C). Variable degrees of predicted habitat suitability were modeled for populations of non-native European Carychium minimum (CM) and C. tridentatum (CT) populations in North America (see Additional files $2 \mathrm{C}$ and Additional file 4). The modeled latitudinal distribution in Eastern North America was interrupted by a large territory of unsuitable bioclimatic conditions. Similar to the native American clade, this phenomenon could be attributed to changes in the variable states of diurnal range (see Additional file 3). Projection of the North and Central American bioclimatic envelope onto Europe largely corresponded with the distribution range of native Carychium taxa (see Additional file 2D). However, a slight shift towards more Mediterranean (to the South) and continental conditions (to the East) was visible.

Bioclimatic niche envelopes of both Carychium clades indicated moderate niche overlap in America (D: 0.3878, I: 0.6885, RR: 0.5998; Table 5). Niche overlap was considerably higher on the European continent (D: 0.6162, I: 0.8570, RR: 0.6589). Niche breadth, i.e. the flatness of the distribution of suitability scores (D. Warren, pers. comm.) differed between both clades with the American clade demonstrating lower values of niche breadth throughout both regions (B1 $1_{\text {America }}<$ $\mathrm{B} 1_{\text {EuropeOntoAmerica }}$ B $1_{\text {AmericaOntoEurope }}<\mathrm{B} 1_{\text {Europe }}$ ) (Table 6).

\section{Discussion}

\section{Unrecognized evolutionary lineages}

While most species concepts view a species as 'a separately evolving metapopulation lineage' [33], they disagree on which characters should be applied to organize this speciation continuum [33]. In the case of the microgastropod taxon Carychiidae, variable environmental conditions can lead to phenotypic variability (e.g. lineages inhabit large geographical regions), whereas relatively stable environments can lead to morphological stasis (e.g. cave endemic lineages) [34-38]. Given that traditional taxonomic classifications completely relied upon characters of the mature shell, unrecognized ELs had to be expected.

Integration of molecular data in a conservative delimitation approach revealed that the 28 analyzed morphospecies actually comprise 43 distinct ELs. From our results, 
Table 4 Model results for the temporal lineage diversification of Carychium and Zospeum

\begin{tabular}{|c|c|c|c|c|c|c|c|c|c|c|c|c|}
\hline model & $\mathbf{P}$ & df & mtype & LH & $\mathrm{r} 1$ & r2 & $a$ & $x p$ & k & st & AIC & $\triangle \mathrm{AIC}$ \\
\hline \multicolumn{13}{|l|}{ threshold } \\
\hline yule2rate & $r 1, r 2, s t$ & 3 & RV & 212.45 & 30.83 & 6.04 & n.a. & n.a. & n.a. & 0.0117 & -418.90 & 0 \\
\hline DDL & $r 1, k$ & 2 & $\mathrm{RV}$ & 208.09 & 37.57 & n.a. & n.a. & n.a. & 68.32 & n.a. & -412.18 & 6.73 \\
\hline pureBirth & r1 & 1 & $\mathrm{RC}$ & 206.58 & 23.71 & n.a. & n.a. & n.a. & n.a. & n.a. & -411.16 & 7.74 \\
\hline DDX & $r 1, x p$ & 2 & $\mathrm{RV}$ & 206.61 & 26.44 & n.a. & n.a. & 0.04 & n.a. & n.a. & -409.21 & 9.69 \\
\hline$b d$ & $r 1, a$ & 2 & $\mathrm{RC}$ & 206.58 & 23.71 & n.a. & 0.00 & n.a. & n.a. & n.a. & -409.16 & 9.74 \\
\hline \multicolumn{13}{|l|}{$A B G D$} \\
\hline yule2rate & $r 1, r 2, s t$ & 3 & RV & 188.50 & 30.78 & 3.65 & n.a. & n.a. & n.a. & 0.0142 & -371.00 & 0 \\
\hline DDL & $r 1, k$ & 2 & RV & 182.55 & 39.38 & n.a. & n.a. & n.a. & 53.63 & n.a. & -361.10 & 9.90 \\
\hline pureBirth & r1 & 1 & $\mathrm{RC}$ & 180.28 & 21.97 & n.a. & n.a. & n.a. & n.a. & n.a. & -358.56 & 12.44 \\
\hline DDX & $r 1, x p$ & 2 & $\mathrm{RV}$ & 180.40 & 27.75 & n.a. & n.a. & 0.08 & n.a. & n.a. & -356.81 & 14.20 \\
\hline$b d$ & $r 1, a$ & 2 & $\mathrm{RC}$ & 180.28 & 21.97 & n.a. & 0.00 & n.a. & n.a. & n.a. & -356.56 & 14.44 \\
\hline \multicolumn{13}{|l|}{ SP } \\
\hline yule2rate & $r 1, r 2, s t$ & 3 & $\mathrm{RV}$ & 226.28 & 31.07 & 4.65 & n.a. & n.a. & n.a. & 0.0096 & -446.56 & 0 \\
\hline DDL & $r 1, k$ & 2 & RV & 221.20 & 36.80 & n.a. & n.a. & n.a. & 78.07 & n.a. & -438.40 & 8.16 \\
\hline pureBirth & r1 & 1 & $\mathrm{RC}$ & 220.00 & 24.58 & n.a. & n.a. & n.a. & n.a. & n.a. & -438.01 & 8.56 \\
\hline$b d$ & $r 1, a$ & 2 & $\mathrm{RC}$ & 220.00 & 24.58 & n.a. & 0.00 & n.a. & n.a. & n.a. & -436.01 & 10.56 \\
\hline DDX & $r 1, x p$ & 2 & $\mathrm{RV}$ & 220.00 & 24.58 & n.a. & n.a. & 0.00 & n.a. & n.a. & -436.01 & 10.56 \\
\hline \multicolumn{13}{|l|}{ GMYCs } \\
\hline yule2rate & $r 1, r 2, s t$ & 3 & $\mathrm{RV}$ & 285.59 & 31.68 & 9.37 & n.a. & n.a. & n.a. & 0.0040 & -565.17 & 0 \\
\hline pureBirth & r1 & 1 & $\mathrm{RC}$ & 283.47 & 29.02 & n.a. & n.a. & n.a. & n.a. & n.a. & -564.93 & 0.24 \\
\hline DDX & $r 1, x p$ & 2 & $\mathrm{RV}$ & 283.78 & 20.50 & n.a. & n.a. & -0.11 & n.a. & n.a. & -563.56 & 1.61 \\
\hline$b d$ & $r 1, a$ & 2 & $\mathrm{RC}$ & 283.52 & 26.48 & n.a. & 0.15 & n.a. & n.a. & n.a. & -563.04 & 2.14 \\
\hline DDL & $r 1, k$ & 2 & $\mathrm{RV}$ & 283.47 & 29.44 & n.a. & n.a. & n.a. & 1927.73 & n.a. & -562.94 & 2.23 \\
\hline \multicolumn{13}{|l|}{ GMYCm } \\
\hline$b d$ & $r 1, a$ & 2 & $\mathrm{RC}$ & 385.03 & 16.10 & n.a. & 0.74 & n.a. & n.a. & n.a. & -766.06 & 0 \\
\hline DDX & $r 1, x p$ & 2 & RV & 384.37 & 12.05 & n.a. & n.a. & -0.35 & n.a. & n.a. & -764.75 & 1.31 \\
\hline yule2rate & $r 1, r 2, s t$ & 3 & $\mathrm{RV}$ & 385.23 & 30.56 & 71.35 & n.a. & n.a. & n.a. & 0.0042 & -764.47 & 1.60 \\
\hline pureBirth & r1 & 1 & $\mathrm{RC}$ & 381.35 & 35.94 & n.a. & n.a. & n.a. & n.a. & n.a. & -760.69 & 5.37 \\
\hline DDL & $r 1, k$ & 2 & $\mathrm{RV}$ & 381.35 & 35.94 & n.a. & n.a. & n.a. & $11.20 \times 10^{-3}$ & n.a. & -758.69 & 7.37 \\
\hline
\end{tabular}

Results are shown for the five different molecular delimitation approaches. Model = model name; $\mathrm{P}=$ parameters included, $\mathrm{df}=\mathrm{degrees}$ of freedom, mytpe $=$ model type; rate-constant $(\mathrm{RC})$ or rate-variable $(\mathrm{RV}), \mathrm{LH}=$ model log likelihood, $\mathrm{r} 1=$ initial diversification rate, $\mathrm{r} 2=$ second diversification rate, $\mathrm{a}=$ extinction fraction, $\mathrm{xp}=$ the $\mathrm{x}$-parameter from the DDX model, $\mathrm{k}=$ the k-parameter from the DDL model, st $=$ shift-time, AIC $=$ Akaike Information Criterion $\triangle \mathrm{AIC}=$ delta AIC, the difference in AIC scores between given model and the overall best-fit model, n.a. = not available.

three different taxonomic scenarios can be distinguished: i) ELs directly matching the morphospecies, including morphologically delimited, but so far, undescribed taxa (21 lineages), ii) distinct ELs being lumped into a single morphospecies (8 morphospecies encompassing 20 lineages), and iii) single ELs including more than one morphospecies hypothesis (4 morphospecies, 1 undescribed taxon, 2 lineages). This suggests that basing carychiid taxonomic delineations only on conchological characters may be inadequate. We emphasize that vague taxonomic (under-) descriptions and semantic tradition, with morphospecies concepts often only referring to a few specimens, have widely neglected aspects such as intraspecific shell variability. In congruence with overlapping, interspecific shell dimensions, this has led to a vague situation in carychiid taxonomy and systematics.

Carychiidae appear to still harbor a considerable amount of undiscovered diversity, especially in biogeographic regions that are underexplored due to political strife, nonaccess and challenging geography, such as Asia or Central America. For example, East Asian C. noduliferum, C. cf. pessimum and the Central American C. mexicanum and C. mexicanum costaricanum morphospecies for which, at least one unrecognized EL was discovered. In Zospeum, 
Table 5 Niche overlap within Carychium in North America and Europe

\begin{tabular}{lccc}
\hline & \multicolumn{3}{c}{ Niche overlap statistic } \\
\hline & $\mathrm{D}$ & $\mathrm{I}$ & relative rank \\
Overlap in North America & 0.3878 & 0.6885 & 0.5998 \\
Overlap in Europe & 0.6162 & 0.8570 & 0.6589 \\
\hline
\end{tabular}

Habitat suitability maps were calculated based on species occurrences in each region (Europe and North America) independently and projected into the other region (North America and Europe, respectively).

similar as in other cave animals [39-41], ELs are likely to be morphologically cryptic, possibly due to morphological stasis.

On the other hand Carychium exile mexicanum most likely served as a 'taxonomic lumping bin' built up by the frequent nomenclatural intermixture of ELs of the morphospecies C. stygium, C. clappi, C. floridanum, C. mexicanum and C. mexicanum costaricanum (e.g. [42-46]). The relevant taxonomic literature is puzzling and contains contradictory statements [42]. In general, individual morphospecies within the $C$. exile mexicanum + C. stygium + C. clappi EL showed highly similar barcode sequences and are thus, difficult to distinguish by molecular delimitation methods, suggesting that these are probably in the process of speciation [18]. A similar complex situation is evident for $C$. tridentatum and Carychium sp. 1, which still need further taxonomic investigation. An alternative explanation for the clustering of morphologically distinguishable taxa may be an artifact created by our conservative genetic delimitation strategy. However, if we expect these 'true' species to be artificially lumped into a single EL, we may equally expect other ELs to include even more 'true' species, e.g. as indicated by the two GMYC models.

Based on our taxonomic investigations, we suggest that apparently widespread and assumedly variable Zospeum morphospecies must be revised. Moreover, since several Zospeum spp. are already listed as vulnerable or endangered [47], we anticipate high conservation value amidst cave-endemics. Furthermore, we recommend that future molecular analyses should focus on populations collected at the type localities, to link an EL with the historic morphospecies hypothesis. A more comprehensive geographic

Table 6 Niche breadth statistic for native and projected models

\begin{tabular}{lc}
\hline & Niche breadth \\
\hline America & 0.326 \\
Europe onto America & 0.374 \\
Europe & 0.549 \\
America onto Europe & 0.472 \\
\hline
\end{tabular}

Niche breadth for Carychium species in Europe and North America as well as according to the projected niches into the other region is shown. sampling would most likely uncover yet even more unrecognized ELs.

\section{Diversification of evolutionary lineages}

Appropriate taxon sampling is crucial for the reconstruction of phylogenetic relationships [30]. Our taxon sampling not only covered large parts of the known Holarctic distribution of the Carychiidae but we integrated molecular data to uncover morphologically unrecognized ELs. As expected, the geographic evolution of Carychiidae suggests that the majority of ELs in a geographic area are phylogenetically more closely related than taxa between distant regions (i.e. continents / mountain ranges). This general pattern is most obvious for the European Carychium and Cantabrian Zospeum. After the initial colonization of new areas due to rare (long-distance) passive dispersal, the ancestral lineages diversified in situ.

Based on five different genetic delimitation approaches, our analyses of diversification modes provided mixed results, and in some cases, indicate that diversification rates may have changed over time. While the two GMYC models favored a constant-rate diversification model, the three more conservative genetic delimitation strategies (threshold, ABGD and SP) point to a relatively recent rate slowdown. Such a rate shift can be interpreted in different ways. First, a decrease in the rate of speciation may be due to diversity dependence, e.g. a niche-filling process, where new species reduce the probability of future speciation events [48]. Second, incomplete taxon sampling can result in a spurious rate slowdown due to an overrepresentation of deeper nodes [49]. Third, since speciation is a continuous process, relatively young divergence events are likely to remain unobserved. This effect has recently been described as 'protracted speciation' [50]. Given that the more conservative delimitation approaches are likely to underestimate the number of ELs, we suggest that the observed pattern is more likely an artifact than an actual slowdown. The other two causes may be difficult to distinguish as they can lead to similar patterns, but we suggest protracted speciation as the most likely cause here. First, while taxon sampling in Carychium and Zospeum is indeed incomplete, several of the missing morphospecies in fact seem to belong to ELs included in this study (for example, C. mariae and C. riparium; [19] and Jochum \& Weigand, unpublished data). Second, the very recent shift in diversification rates is expected under protracted speciation, but could result from incomplete taxon sampling only if the missing species were those that have originated most recently. After omitting the youngest 5th percentile of total branch lengths (i.e. excluding the most recent $5 \%$ of the evolutionary history), a constant-rate model is also favored for the threshold, ABGD and SP partitions (data not shown). This not only highlights the very recent timing of the rate 
shift (consistent with protracted speciation), but it also shows that no additional rate shifts throughout the evolutionary history of Carychiidae have occurred, suggesting that major environmental changes did not affect the rate of diversification of this clade.

The geographic evolution of Carychium implies an Asian or Asian + North American origin. Asian Carychium are the genetically most distinct. Since high regional genetic diversity of a taxon can be taken as evidence for lineage persistence in ancestral areas [51], this provides support for an out-of-Asia hypothesis. Niche models suggest significant overlap and occupancy of a wide range of environmental conditions among two geographically and phylogenetically distant Carychium clades (Europe and America). There is, however, no evidence for an intermixture of the East and West North American Carychium lineages. Thus, larger-scale bioclimatic factors are likely to have been of lesser importance than microhabitat conditions in the diversification of Carychium. Nonetheless, differences in the larger-scale bioclimatic niche can result from independent evolutionary histories in isolated biomes and, affect the marginal distribution of lineages. For example diurnal range patterns, an important factor for North American Carychium, might affect the colonization of habitats featuring a high variation between day and night. Temperature extremes, moisture and relative humidity levels in typical microhabitats occupied by Carychium (e.g. moist leaf-litter, crevices or superficial subterranean habitats) are much less pronounced than those on the surface [52-54]. In cases where the temperature diurnal range is high, microhabitats will not be able to stabilize a given condition.

Since the available bioclimatic layers do not cover subterranean habitats, the influence of bioclimatic parameters on the distribution and diversification of Zospeum could not be addressed. The ancestral area reconstruction indicated the 'Cantabrian Mountains + Alps' or 'Cantabrian Mountains + Dinaric Alps' as the ancestral area. We identified two independent colonizations of the Alps and/or the Dinaric Alps but the geographical directionality of these colonizations could not yet be deduced. The incorporation of a recently (re)discovered Asian cf. Zospeum from Chinese and South Korean caves (RS and [55]) may provide further insight into the evolutionary history of Zospeum.

The diversification of Zospeum is characterized by rare, long-distance colonization events with in situ (mountain range) radiations into several (sometimes morphologically cryptic) lineages, occupying isolated cave systems. Trogloxene cave animals like bats and cave crickets, returning to the surface periodically, represent potential vectors for the passive dispersal of cave-dwelling microgastropods $[56,57]$. Such an allopatric diversification without phenotypic (and perhaps ecological) divergence is referred to as morphostatic radiation [58] or non-adaptive radiation [59]. Once established at a new locality, ancestral populations may reach adjacent habitats by floating via underground drainage systems or by active subsurface migration [40]. As an example, seasonal flooding events are known triggers for the wash-out of the cave salamander Proteus anguinus [60]. As has been shown for humandispersed transatlantic populations of Carychium [26,27], the transportation of only a few hermaphroditic individuals is needed for a successful population foundation. Finally, the remarkably wide distribution of the Cantabrian Zospeum sp. 1 with the presence of identical DNA barcodes in four distant caves (up to $30 \mathrm{~km}$ apart) suggests recent long-distance dispersal and merits further investigation.

In contrast to the aforementioned, dispersal colonization, cave lineages can arise from multiple diversification events of surface populations via vicariance colonization [56,61]. The geographic distribution of extant Zospeum allows room for speculation about the maximum age and evolutionary history for this group. All caves inhabited by European Zospeum are embedded in sediments of the Alpine belt initially formed during the Early Cenozoic Alpine orogeny [62,63]. Our most parsimonious assumption suggests that European Zospeum originated no earlier than the beginning of the Early Cenozoic (approximately 65 mya), coinciding with the beginning of the Alpine orogeny. Their last common ancestor (LCA) could have descended from the noncave-dwelling Carychiopsis, for which fossils are known since the European Paleocene (66-56 mya) [64-66].

\section{Conclusions}

Carychiidae harbor a substantial number of morphologically unrecognized ELs. In particular, several of the assumedly widespread cave-dwelling Zospeum as well as Asian and Central American Carychium species resulted from past taxonomic lumping. Future studies should focus on specimens from type localities to link the ELs with the initial phenotype descriptions. Rare longdistance colonization and in situ radiations within the newly inhabited areas, i.e. continents (Carychium spp.) and mountain ranges (Zospeum spp.) represent likely diversification processes in the Carychiidae. However, East Asia provides a notable exception, exhibiting high regional genetic diversity formed by several distinct Carychium lineages: indicating a potential origin for Carychium and a potentiality for all the Carychiidae.

Although global climatic conditions could influence distribution, microhabitat structure most likely determined local presence and promoted allopatric diversification. Land invasion and desiccation avoidance by the LCA of Carychiidae could have been achieved by colonizing aphotic, permanently humid microenvironments. The occurrence of a true, cave-dwelling lineage (Zospeum) and 
sporadically-observed cave populations in Carychium only demonstrate ecological extremes for survival during the adaptive shift onto land. Shallow subterranean habitats, providing a connection between surface and subsurface realms, could well have promoted ecological transitions within the Carychiidae. Future species-specific ecological studies will allow the identification of micro-environmental parameters shaping the distribution and promoting lineage diversification.

\section{Methods}

\section{Sampling and identification}

In total, 166 individuals were collected during the years 2007-2012 (Table 1). Specimens were immediately stored in 70-99 \% ethanol after collection. Our dataset comprises 28 morphologically-described (sub-) species (referred to as morphospecies) of the Carychiidae, including 18 Carychium (Figure 1) and 10 Zospeum taxa (Figure 2). Additional data were retrieved from a previous DNA barcoding study [18]. Initial taxonomic assignments are based upon conchological characters using taxonomic first descriptions, expert opinions (AJ and AMW [Carychium+Zospeum]; E. Gittenberger and R. Bank [European Carychium]; Y. Kano [Japanese Carychium]; RS and C.E. Prieto [Zospeum]) and relevant taxonomic keys (e.g. [42,46,67-69]). Morphospecies assignments are marked with 'cf.' in case of juvenile specimens or tenuous morphological characteristics. In particular, the specimens 27-29 from Epirus (Greece) do not match any description of extant taxa but very much resemble $C$. schlickumi described from the Pliocene [70].

\section{DNA extraction, PCR and sequencing}

DNA extraction was carried out on ethanol-preserved individuals using the DNeasy Blood and Tissue Kit (Qiagen, Hilden, Germany) protocol. Shell and visceral material were removed to lower cross-contamination risk. Polymerase chain reactions (PCR) were performed to amplify nuclear Histone $3(\mathrm{H} 3)$, a partial fragment of the mitochondrial 16S rRNA (16S) and the DNA barcoding fragment of the mitochondrial-encoded Cytochrome C Oxidase Subunit I (COI). For COI, we used the standard invertebrate primer pair LCO1490 - 5'GGT CAA CAA ATC ATA AAG ATA TTG G-3' and HCO2198 - 5'-TAA ACT TCA GGG TGA CCA AAA AAT CA-3' [71]. Each $25 \mu \mathrm{L}$ PCR mixture included $1 \mu \mathrm{L}$ (10 pmol) of each primer, $2.5 \mu \mathrm{L}$ 10x PCR buffer, $2 \mu \mathrm{L}$ $(100 \mathrm{mM}) \quad \mathrm{MgCl}_{2}, 0.3 \mu \mathrm{L}(20 \mathrm{mM})$ dNTPs, $0.3 \mu \mathrm{L}$ Taq-polymerase, $0.25 \mu \mathrm{L}(0.5 \mathrm{M})$ tetramethylammonium chloride, $1.5 \mu \mathrm{L}(10 \mathrm{mg} / \mathrm{mL}$ ) bovine serum albumin,

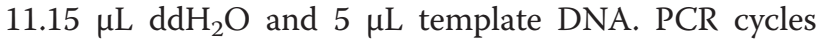
were run at the following conditions: $1 \mathrm{~min}$ at $95^{\circ} \mathrm{C}$, followed by 30 cycles of $30 \mathrm{~s}$ at $95^{\circ} \mathrm{C}, 30 \mathrm{~s}$ at $52^{\circ} \mathrm{C}$ and $30 \mathrm{~s}$ at $72^{\circ} \mathrm{C}$, and finally, $3 \mathrm{~min}$ at $72^{\circ} \mathrm{C}$. For $16 \mathrm{~S}$, we used the same PCR conditions and the primer pair 16S-H 5'-CGC CTG TTT ATC AAA AAC AT-3' and 16S-R 5'-CCG GTC TGA ACT CAG ATC ACG T-3' [72]. For $\mathrm{H} 3$, we used the degenerated primer pair $\mathrm{H} 3-\mathrm{F}-$ 5'-ATG GCT CGT ACC AAG CAG AC(ACG) GC-3' and H3-R - 5'-ATA TCC TT(AG) GGC AT(AG) AT (AG) GTG-3' [73]. In principle, the same PCR conditions have been used for the amplification of the $\mathrm{H} 3$ marker. Modifications contain: the use of $0.1 \mu \mathrm{L}$ $(20 \mathrm{mM}) \mathrm{dNTPs}, 0.14 \mu \mathrm{L} \mathrm{Taq}$-polymerase and no tetramethylammonium chloride and bovine serum albumin. PCR cycles were run at the following conditions: $5 \mathrm{~min}$ at $95^{\circ} \mathrm{C}$, followed by 34 cycles of $30 \mathrm{~s}$ at $95^{\circ} \mathrm{C}, 25 \mathrm{~s}$ at $52^{\circ} \mathrm{C}$ and $45 \mathrm{~s}$ at $72^{\circ} \mathrm{C}$, and finally, $5 \mathrm{~min}$ at $72^{\circ} \mathrm{C}$. Visualization of single PCR products was performed on a $1.4 \%$ agarose gel. They were cleaned using the GeneJET PCR Purification Kit (Fermentas, St. Leon-Rot, Germany). In cases multiple PCR products were detected, the QIAquick Gel Extraction protocol (Qiagen) was used. PCR products were bidirectionally sequenced using the PCR primer pair $(5 \mathrm{pmol})$ and the BigDye ${ }^{\circledR}$ Terminator v.3.1 Cycle Sequencing Kit (Applied Biosystems, Inc.) on an ABI $3730 \mathrm{xl}$ capillary sequencer following the manufacturer's instructions.

\section{Molecular delimitation strategies}

COI sequences of all 166 individuals were aligned using MAFFT 6.814 [74] implemented in the Geneious software under the G-INS -i algorithm proposed for less than 200 sequences with global homology. Ambiguous characters (Ns) were treated as missing data. The alignment was further modified by manual primer deletion and a 3 ' and 5' trimming conducted with GBLOCKS [75]. The length of the final alignment was $607 \mathrm{bp}$. DNA barcodes are deposited in the BOLD project 'Barcoding Carychiidae microsnails [BARCA]'.

Initial morphospecies assignments were tested using five genetic delimitation approaches: DNA barcoding via a threshold value [76], the Automatic Barcoding Gap Detection (ABGD) method [77], the General Mixed Yule-Coalescent single (GMYCs) and multiple (GMYCm) models [78,79] and Statistical parsimony network analysis (SP) [80]. A threshold value of 3.2\% K2P genetic distance was used to separate intra- and interspecific variability in Carychiidae, as recently established by Weigand et al. [18]. The ABGD method separates DNA sequences based on an automatic procedure of barcode gap discovery. Three user defined input variables are requested: The minimum (Pmin) and maximum intraspecific variability (Pmax), which refer to the area were the barcode gap should be detected; and the minimum gap width $(\mathrm{X})$ which relates to the sensitivity of the method to gap width. We tested model combinations of $\mathrm{X}$ ranging from 0.01 to 0.9 with Pmax of 0.001 and 0.9 , respectively. All runs were 
performed using Kimura (K89) genetic distances and 50 screening steps. The GMYC delimitation method combines phylogenetic and phylogeographical approaches to estimate the number of well-separated entities in a sample. It uses an ultrametric input tree to define partitions according to transitional points between speciation and coalescence within species rates. A model based on a single (GMYCs) or multiple (GMYCm) threshold values can be tested. Analyses and model comparisons were performed in the R package 'Splits' using the 'gmyc' and 'compare' functions. The ultrametric input tree was obtained with BEAST v1.7.4. [81]. Statistical parsimony network analysis (SP) is commonly used to cluster haplotypes in a phylogeographical framework [82]. However, an inverse consideration of this method is proposed to allow the delimitation of coalescent populations [80]. The program TCS 1.21 [83] was used to delimitate entities on the basis of $95 \%$ statistical confidence (i.e. connection probability).

\section{Alignment optimization and phylogenetic tree reconstruction}

Phylogenetic hypotheses were reconstructed using a concatenated dataset of three phylogenetic markers (mitochondrial 16S, COI and nuclear H3) resulting in $1210 \mathrm{bp}$. In total, 86 individuals comprising 26 carychiid morphospecies (17 Carychium, 9 Zospeum) and 38 ELs as well as three outgroup taxa (Ellobioidea: Pythiidae: Laemodonta cubensis; Ellobioidea: Melampodidae: Microtralia occidentalis and Veronicelloidea: Veronicellidae: Veronicella cubensis) were analyzed for the concatenated dataset (see Additional file 5). Alignment optimization was performed separately for each phylogenetic marker: 16S sequences were aligned with MAFFT 6.814 under the FFT-NS -i x 1000 algorithm implemented in the Geneious software. The initial $16 \mathrm{~S}$ alignment had a length of $548 \mathrm{bp}$. Primer sequences were deleted and the initial alignment was further modified with GBLOCKS [75] to remove ambiguously aligned internal positions and to trim the alignment at the 5' and 3' ends. The final $16 \mathrm{~S}$ alignment had a length of $368 \mathrm{bp}$ ( $67 \%$ of the initial alignment). For the nuclear H3 marker, the G-INS -i algorithm was used. Primer deletion and GBLOCKS 5' and 3' trimming resulted in $235 \mathrm{bp}$ of the initial $330 \mathrm{bp}$ (71\%). The already trimmed barcoding alignment was used as the COI alignment (607 bp, 93\% of initial alignment).

Topologies were estimated under three different phylogenetic reconstruction methods: Maximum Composite Likelihood (MCL), Maximum Likelihood (ML) and Bayesian inference (BI). Runs for MCL were performed in MEGA5 under the pairwise deletion option, a gamma distribution $(\mathrm{G})$ with rate parameter 1 and 1,000 bootstrap replicates. RaxML 7.0.3 [84] was used to estimate the ML topology. To account for varying substitution rates between different loci and nucleotide positions, three marker-specific partitions under the GTR+G+I substitution model were set. MrModeltest 2.3 was used to distinguish between competing substitution models [85]. A thorough ML bootstrapping with 1,000 replicates was conducted. A Bayesian phylogenetic analysis was performed with MrBayes 3.2.1 [86,87] using Veronicella cubensis as outgroup. Three gene partitions were defined keeping the estimation of all parameters of the GTR+G+I model of evolution unlinked during the analysis. Two runs of 2,000,000 generations of the MCMC (Markov Chain Monte Carlo) were executed, sampling every 500 generations. The first $25 \%$ of the samples were discarded as burn-in to ensure sampling from the stationary phase of the model runs. The chain temperature parameter was set at 0.1 . At the $2,000,000^{\text {th }}$ generation, the average standard deviation of split frequencies had already fell below 0.01, thus the analysis was stopped.

The concatenated alignment and the phylogenetic consensus hypothesis are deposited in TreeBASE (http:// purl.org/phylo/treebase/phylows/study/TB2:S13629).

\section{Alternative hypotheses testing}

A model selection approach using BEAST v1.7.4 [81,88] was followed to test the monophyly of geographical closely-distributed taxa. Four taxon sets of species inhabiting a certain geographic area were created and constrained to be monophyletic, i.e. i) American Carychium, ii) Asian Carychium, iii) Dinaric Zospeum and iv) Alpine Zospeum. The monophyletic constraints were analyzed independently and compared with the results of the unconstrained topology. The Markov Chain Monte Carlo was run for 30 million generations, sampling trees and parameters every 1,000 generations. After verifying that appropriate effective sample sizes were achieved, three model selection methods were applied: a posterior simulation-based analogue of the Akaike Information Criterion (AICM) [89,90], and Bayes Factors (BF) between marginal likelihoods estimated through Path Sampling (PS) [91] and Stepping Stone Sampling (SS) [92]. We used the settings suggested on the BEAST website (http://beast.bio.ed.ac.uk/Model_selection). Competing topological hypotheses were ranked according to the results of the AICM and the marginal likelihood values obtained with PS and SS. Differences between AIC were calculated ( $\triangle \mathrm{AICM})$ as were Bayes Factors between competing hypotheses. A $\Delta>7$ between AICM values of the best ranked hypothesis and the other hypotheses suggests that the latter are very unlikely [93]. A Bayes Factor $_{\text {ln }}>2.3$ was considered as strong support for the hypothesis (modified guidelines of [94]).

\section{Estimation of relative times of divergence}

The scarcity of reliable fossils of Carychium hinders the estimation of absolute times of divergence. Carychium 
brotianum De Loriol, 1865 from the Upper Jurassic in France is assumed to be by far the oldest carychiid fossil [95]. Our own investigations of the type material of Carychium brotianum deposited in the Musée Cantonal de Géologie Lausanne reject a close affiliation to Carychiidae. We rather regard the extinct lineage Carychiopsis Sandberger, 1872 known from the Paleocene until the Neogene or Carychium munieri Briart \& Cornet, 1889 reported from the Early Paleocene as the oldest representatives of Carychiidae [64-66,96]. In respect to this problem, we chose to estimate only relative ages. The analysis was performed with the program BEAST v1.6.1 [81] using an uncorrelated, relaxed lognormal molecular clock model. The three genetic markers were concatenated but the parameters of the substitution and molecular clock models were independently estimated for each gene partition. The taxa Veronicella cubensis, Microtralia occidentalis and Laemodonta cubensis formed the outgroup taxa set. Trees were sampled from a Birth-Death tree-prior and following the GTR+G+I substitution model. The MCMC was run for 30,000,000 generations sampling trees and parameters every 1,000 generations. Effective sample size and convergence were evaluated in Tracer 1.5 [97]. The first $10 \%$ of samples were discarded as burn-in before building the maximum clade credibility (MCC) tree.

\section{Temporal patterns of diversification}

To assess the temporal dynamics of lineage diversification, we tested several constant- and variable-rate models of diversification using a maximum likelihood approach as implemented in the $\mathrm{R}$ package laser $[98,99]$. Model-fit was evaluated using the Akaike Information Criterion (AIC) [90]. Temporal changes in the net diversification rate were evaluated by calculating the difference in the AIC score between the best fit constant-rate (pure-birth, birth-death) and variable-rate models (DDL, DDX, yule2rate). Since these comparisons are susceptible to a high Type I error rate [98], a null distribution of the test statistic was generated by calculating the $\triangle \mathrm{AIC}$ score for 500 phylogenetic trees simulated under a pure-birth process.

\section{Geographic range evolution}

The dispersal-extinction-cladogenesis (DEC) model implemented in Lagrange [100] was used to infer geographic range evolution. The model assumes that geographic splits for a given lineage occur along the branches of a topology rather than at bifurcation points. Changes in the geographic range of a given taxon can be accounted for by dispersal events (range expansion) or local extinction (range contraction). Alternative Lagrange analyses were run with the maximum range size set to either two or four (the maximum number of areas in the model). The patterns were largely congruent and only the results of the conservative approach are presented in which taxa are allowed a maximum range size of two, i.e. simultaneously inhabiting up to two geographic areas (here continents or mountain ranges). Given their low dispersal potential and the high proportion of continent- or cave-endemic taxa, this scenario seems more likely. The character state with the highest relative probability (fraction of the global likelihood) was plotted on the topology. In cases of similar relative probability values, all alternative scenarios were plotted to account for model uncertainty.

\section{Bioclimatic niche modeling}

Bioclimatic niche models were constructed with the program Maxent 3.3.3 [101]. This approach is based on the principle of least assumptions. In the absence of any further information, it prefers the model with the maximum entropy. Niche parameters are extracted from occurrence points and global environmental layers and combined into taxon-specific bioclimatic envelopes. We used georeferenced data for monophyletic lineages instead of species-specific data because ambiguous species-level identifications of Carychium taxa are likely to produce questionable entries in public databases or museum collections. The investigation of the bioclimatic niche and macro-evolutionary changes above the species level has proven suitable in earlier studies [102]. This is understandable as traits that allow taxa to persist tend to be conserved over time [102]. The bioclimatic niches for i) the monophyletic European Carychium clade and ii) the monophyletic North + Central American (NC) Carychium clade were estimated. In total, 136 sampling points for the European clade were collected either from our own collections or the GBIF database (www.gbif. org). Data from American museum collections (Carnegie Museum of Natural History, Pittsburgh; Field Museum of Natural History, Chicago; Florida Museum of Natural History, Gainesville) and entries within the GBIF database are used as distribution data for the NC-clade resulting in 241 sampling points for this model. All 19 bioclimatic variables of the WorldClim project [103] were used in highest resolution $(\sim 30$ arc-seconds $)$ in order to discover potential, fine-scale patterns affecting the distribution of carychiid microgastropods. Almost all included georeference points (>98\%) were accurate to about less than $1 \mathrm{~km}$, which justifies the implementation of bioclimatic variables in their highest resolution. We performed five cross-validated Maxent runs and considered grid cells with a cumulative probability of more than 10 (from a range of $0-100$ ) as suitable [104,105]. The area under the ROC curve (AUC) gave an evaluation of the projections' overall quality. An AUC score above 0.7 is considered good model performance [106]. Outputs are generalized clade-based models. Such a model design can slightly overestimate taxon-specific 
bioclimatic envelopes and can lead to false-positive model results (i.e. predicted habitat suitability but biological absence of taxa).

\section{Niche similarity}

ENMtools [107] was used for the comparative analysis of environmental niche models of the European and NCclade. Niche overlap between the two clades was assessed using three different similarity statistics: Schoener's D [108], the I statistic [109], and the relative rank test [110]. Schoener's D and I calculate the difference in standardized suitability scores for each grid cell. The relative rank test provides an estimate of the congruence of relative ranks of suitability for each grid cell. All three measurements can have a range between 0 (non-overlapping niches) and 1 (identical niches). To calculate niche similarity, climatic niche models were cross-projected onto the geographic region of the other clade.

\section{Additional files}

Additional file 1: Figure *.tif. Schematic visualization for the constrained model selection approaches. The unconstrained phylogenetic hypothesis was tested against four competing evolutionary scenarios in a model selection approach (refer to Table 3). Both scenarios concerning Carychium microgastropods are depicted, since the constraints likewise affected the splitting order of ancient nodes. $\mathrm{E}=$ Europe; $\mathrm{A}=$ Asia; $\mathrm{N}+\mathrm{C}=$ North+Central America excl. $\mathrm{C}$. nannodes; $\mathrm{N}=\mathrm{C}$. nannodes. Black dots indicate posterior probability $\geq 0.98$. $A$ : phylogenetic unconstrained hypothesis. $A_{1 a}=C$. cf. pessimum; $A_{1 b}=C$. nipponense; $A_{2}=$ Carychium sp. $3 ; A_{3}=C$. cf. noduliferum. B: monophyletic Asian Carychium. C: monophyletic American Carychium. $\mathrm{A}_{1}=\mathrm{C}$. cf. pessimum + C. nipponense; $A_{2}=C$. cf. noduliferum + Carychium sp.3.

Additional file 2: Figure *.tif. Bioclimatic niche models. The suitable bioclimatic conditions of the native monophyletic North + Central American ( $\mathrm{A}$; red) and European ( $\mathrm{B}$; yellow) clades are illustrated. Niche projections for these clades and between the areas are depicted in $C$ and D. Black triangles indicated occurrence data of native (in A and B) and schematic snails of introduced taxa (in C). A: Potential distribution of the native North + Central American clade. B: Potential distribution of the native European clade. C: Projected distribution of the European clade in North + Central America. Non-native European Carychium minimum (CM) and C. tridentatum (CT) populations are indicated. D: Projected distribution of the North + Central American clade in Europe.

Additional file 3: Figure *.tif. Distribution of bio2 (diurnal range) in North and Central America (TIFF 807 kb). North and Central American diurnal range values have a minimum of 1.8 (black) and a maximum of 21.4 (white) degrees Celsius $\left({ }^{\circ} \mathrm{C}\right)$.

Additional file 4: Table *.xlsx. Non-native Carychium populations in North America. Locality information and literature sources for non-native Carychium populations (based on morphospecies IDs) in North America are listed. Specimens from localities indicated by an asterisk $\left(^{*}\right)$ are validated by DNA barcoding as the respective Carychium species [111-116].

Additional file 5: Table *.xlsx. BOLD barcode identifier (COI) and NCB accession numbers (16S and $\mathrm{H} 3$ ). EL = evolutionary lineage; \# = specimen number. ${ }^{1}$ type locality population, regarded as $C$. costaricanum. ${ }^{2}$ cave population from region mentioned in phenotype description of $Z$. isselianum. ${ }^{3}$ type locality population of $Z$. spelaeum schmidti. ${ }^{4}$ cave population of $Z$. suarezi from cave locality mentioned in phenotype description, ${ }^{5} \mathrm{H} 3$ sequence of $\# 152$ upon request (too short for GenBank deposition).

\section{Competing interests}

The authors declare that they have no competing interests.

\section{Authors' contributions}

AMW, JS, AJ and AKK designed the study. AJ, AMW and RS collected the specimens. AWM produced the sequences and together with JS acquired the biostatistical data. AMW, JS and EZ conducted the biostatistical analyses. AMW was responsible for the first draft of the manuscript. All authors gave conceptual comments, read and approved the final manuscript.

\section{Acknowledgements}

AKK, EZ and JS were supported by the funding programme 'LOEWE-LandesOffensive zur Entwicklung Wissenschaftlich-ökonomischer Exzellenz' from the Ministry of Higher Education, Research, and the Arts, Hesse, Germany. We wish to thank all the following carychiid-savy biologists, malacologists and museum curators who kindly collected material for us, provided valuable insights, lent us museum material or endured scanning marathons in order to relay us rare literature. Without their generous help, the comprehensive scope of this work could never have been realized: J. Ablett (NHM, UK), R. Bank (Netherlands), M. Bodon (Italy), S. Castillo (Panama), D. Dourson (Belize), R. Egorov (Russia), S. \& S. Geiger (Germany), S. Cianfanelli (NHM "La Specola", Italy), J. Gerber (FMNH, USA), B. Gomez (Spain), B. Gregory (USA), A. Favre (Germany), F. Hardie (USA), D. Holyoak (Portugal), C. Holiday (USA), E. Gittenberger (Naturalis, Netherlands), K. Groh (Germany), R. Janssen (SMF, Germany), A. Komerički (HBSD, Croatia), F. Naggs (NHM, UK), J. Nekola (USA), E. Neubert (NMBE, Switzerland), R. Ozimec (Croatia), B. Páll-Gergely (Hungary), S. Pezet (MNHM, France), D. Geogiev (Bulgaria), D. Teixeira (Madeira), I. Richling (SMNS, Germany), J. J. Lewis (USA), J. Slapcinsky (FLNHM, USA), K. Kimura (Japan), C. E. Prieto (Spain), L. Prozorova (Russia), M. Prodan (Italy), M. Schilthuizen (Naturalis, Netherlands), M. Neiber (Germany), M. Horsák (Czech Rep.), S. R. Smith (BNHM, Bermuda), F. Stoch (Italy), F. Giusti (Italy), G. Rosenberg (ANSP, USA), T. Pearce (CMNH, USA), U. Boeßneck (Germany), Y. Kano (AORI, Japan), Z. Fehér (HNHM, Hungary), J. Valentinčič (Slovenia), T. Worsfold (UK), M. Wu (China), E. Zarza (Germany), and C. Zinßmeister (Germany). We also want to thank S. Telle, M. Piepenbring, T. Hofman, I. Richling and $\mathrm{O}$. Caceres for helping us to obtain collection permits in Panama and Costa Rica. Specimens from the latter region refer to museum vouchers MZUCR250, MZUCR251 and MZUCR252. We acknowledge the support of the Bermuda Aquarium, Museum and Zoo as part of the Department of Conservation Services. This is contribution \#196, Bermuda Biodiversity Project (BBP), Bermuda Aquarium, Natural History Museum and Zoo. Finally, we highly appreciate the constructive input of two anonymous reviewers and the editor on earlier versions of this manuscript.

\section{Author details}

${ }^{1}$ Department of Phylogeny and Systematics, Institute for Ecology, Evolution and Diversity, Biosciences, Goethe-University Frankfurt, Max-von-Laue Straße 13, 60438, Frankfurt am Main, Germany. ${ }^{2}$ Institute of Biology, Center for Scientific Research of the Slovenian Academy of Sciences and Arts, Novi trg 2, p.p. 306, 1000, Ljubljana, Slovenia. ${ }^{3}$ Biodiversity and Climate Research Centre, Senckenberganlage 25, 60325, Frankfurt am Main, Germany.

Received: 20 September 2012 Accepted: 14 January 2013

Published: 23 January 2013

\section{References}

1. Albertson RC, Markert JA, Danley PD, Kocher TD: Phylogeny of a rapidly evolving clade: the cichlid fishes of Lake Malawi, East Africa. Proc Nat Acad Sci USA 1999, 96:5107-5110.

2. Robe $\sqcup$, Loreto ELS, Valente VLS: Radiation of the, Drosophila“ subgenus (Drosophilidae, Diptera) in the Neotropics. J Zool Syst Evol Res 2010, 48:310-321.

3. Smith BT, Klicka J: The profound influence of the Late Pliocene Panamanian uplift on the exchange, diversification, and distribution of New World birds. Ecography 2010, 33:333-342.

4. Avise JC: Phylogeography: The history of formation of species. Cambridge: Harvard University Press; 2000.

5. Zeisset I, Beebee TJC: Amphibian phylogeography: a model for understanding historical aspects of species distributions. Heredity 2008, 101:109-119.

6. Morton JE: The evolution of the Ellobiidae with a discussion on the origin of the Pulmonata. P Zool Soc Lond 1955, 125:127-168. 
7. De Frias Martins AM: Morphological and anatomical diversity within the Ellobiidae (Gastropoda, Pulmonata, Archaeopulmonata). Vita Malacologica 2007, 4:1-28.

8. Barker GM: The Biology of Terrestrial Molluscs. UK: CABI Publishing, Oxon; 2001

9. De Frias Martins AM: Relationships within the Ellobiidae. In Origin and evolutionary radiation of the Mollusca. Edited by Taylor J. Oxford: Oxford University Press, Oxford; 1996:285-294.

10. De Frias Martins AM: Anatomy and systematics of the western Atlantic Ellobiidae (Gastropoda: Pulmonata). Vita Malacologia 1996, 37:163-332.

11. Odhner NH: Marinula juanensis n. sp., nebst Bermerkungen über die Systematik der Ellobiiden. Ark Zool 1925, 17A:1-15.

12. White TR, Conrad MM, Tseng R, Balayan S, Golding R, de Frias Martins AM, Dayrat BA: Ten new complete mitochondrial genomes of pulmonates (Mollusca: Gastropoda) and their impact on phylogenetic relationships. BMC Evol Biol 2011, 11:295.

13. Dayrat B, Conrad M, Balayan S, White TR, Albrecht C, Golding R, Gomes S, Harasewych MG, de Frias Martins AM: Phylogenetic relationships and evolution of pulmonate gastropods (Mollusca): new insights from increased taxon sampling. Mol Phylogenet Evol 2011, 59:425-437.

14. Klussmann-Kolb A, Dinapoli A, Kuhn K, Streit B, Albrecht C: From sea to land and beyond: new insights into the evolution of euthyneuran Gastropoda (Mollusca). BMC Evol Biol 2008, 8:57.

15. Bulman K: Shell variability in Carychium tridentatum (Risso, 1826) and its importance for infraspecific taxonomy (Gastropoda, Pulmonata: Ellobiidae). Malak Abh Mus Tierkd Dresden 1990, 15:37-50.

16. Nekola JC, Barthel M: Morphometric analysis of the genus Carychium in the Great Lakes region. J Conchol 2002, 37:515-531.

17. Jochum A: Evolution and diversity of the troglobitic Carychiidae - A morphological and phylogenetic investigation of the terrestrial ellobioid genera, Carychium and Zospeum. Malacologist 2011, 57:16-18.

18. Weigand AM, Jochum A, Pfenninger M, Steinke D, Klussmann-Kolb A: A new approach to an old conundrum - DNA barcoding sheds new light on phenotypic plasticity and morphological stasis in microsnails (Gastropoda, Pulmonata, Carychiidae). Mol Ecol Resour 2011, 11:255-265.

19. Weigand AM, Goetze M-C, Jochum A: Outdated but established?! Conchologically driven species delineations in microgastropods (Carychiidae, Carychium). Org Divers Evol 2012, 12:377-386.

20. Nekola JC, Barker GM, Cameron RAD, Pokryszko BM: Latitudinal and longitudinal variation of body size in land snail populations and communities. In Global patterns of body size. Edited by Smith F, Lyons K. Chicago: University of Chicago Press; In press.

21. Aubry S, Labaune $C$, Magnin F, Roche $P$, Kiss L: Active and passive dispersal of an invading land snail in Mediterranean France. J Anim Ecol 2006, 75:802-813.

22. Slapnik R: Activity and movements of Zospeum isselianum Pollonera 1886 (Gastropoda, Pulmonata, Carychiidae) in a cave in the KamniškeSavinjske Alps (Slovenia). Nat Croat 2001, 10:153-162.

23. Weigand AM, Pfenninger M, Jochum A, Klussmann-Kolb A: Alpine crossroads or origin of genetic diversity? Comparative phylogeography of two sympatric microgastropod species. PLoS One 2012, 7(5):e37089.

24. Vagvolgyi J: Body size, aerial dispersal, and origin of the Pacific Land Snail Fauna. Syst Biol 1975, 24:465-488.

25. Gittenberger E, Groenenberg DSJ, Kokshoorn B, Preece RC: Molecular trails from hitch-hiking snails. Nature 2006, 439:409

26. Pearce TA, Payne SL: First record of the European land snail Carychium minimum in Pennsylvania, USA. Tentacle 2011, 19:13-14

27. Weigand AM, Jochum A: Mollusca, Gastropoda, Ellobioidea, Carychium minimum O.F. Müller, 1774: filling gaps. New population record for the State of New York, northeastern United States. Check List 2010, 6:517-518.

28. Puillandre N, Modica MV, Zhang Y, Sirovich L, Boisselier MC, Cruaud C, Holford M, Samadi S: Large-scale species delimitation methods for hyperdiverse groups. Mol Ecol 2012, 21:2671-2691.

29. Haszprunar G: Species delimitations - not 'only descriptive'. Org Divers Evol 2011, 11:249-252.

30. Heath TA, Hedtke SM, Hillis DM: Taxon sampling and the accuracy of phylogenetic analyses. J Syst Evol 2008, 46:239-257.

31. Gittenberger $\mathrm{E}:$ Three notes on Iberian terrestrial gastropods. Zool Meded 1980, 55:201-213.

32. Von Martens E: Land and Freshwater Mollusca. In Biologia CentraliAmericana. Edited by Godman FD, Salvin O. London:; 1890:1901-353.
33. De Queiroz K: Species concepts and species delimitation. Syst Biol 2007, 56:879-886.

34. Trussell GC: Phenotypic plasticity in an intertidal snail: the role of a common crab predator. Evolution 1996, 50:448-454

35. Hollander J, Collyer ML, Adams DC, Johannesson K: Phenotypic plasticity in two marine snails: constraints superseding life history. J Evol Biol 2006, 19:1861-1872

36. Hollander J, Butlin RK: The adaptive value of phenotypic plasticity in two ecotypes of a marine gastropod. BMC Evol Biol 2010, 10:333.

37. Wake DB, Roth $\mathrm{G}$, Wake $\mathrm{MH}$ : On the problem of stasis in organis-mal evolution. J Theor Biol 1983, 101:211-224.

38. West-Eberhard MJ: Phenotypic plasticity and the origins of diversity. Annu Rev Ecol Syst 1989, 20:249-278.

39. Lefébure T, Douady CJ, Gouy M, Trontelj P, Briolay J, Gibert J: Phylogeography of a subterranean amphipod reveals cryptic diversity and dynamic evolution in extreme environments. Mol Ecol 2006, 15:1797-1806.

40. Culver DC, Pipan T: Biology of Caves and Other Subterranean Habitats. Oxford: U.K., Oxford University Press; 2009

41. Wright S: The roles of mutation, inbreeding, crossbreeding, and selection in evolution. Genetics: Proceedings of the Sixth International Congress on; 1932:355-366.

42. Pilsbry HA: Land Mollusca of North America (north of Mexico), 2(2). Philadelphia: Academy of Natural Sciences of Philadelphia, Monographs 3; 1948.

43. Pilsbry HA: Forms of American Carychium. Nautilus 1891, 4:109-110.

44. Pilsbry HA: The American species of Carychium. Nautilus 1894, 8:61-63.

45. Clapp GH: Notes on Carychium and description of a New variety. Nautilus 1906, 14:138-140.

46. Burch JB, Van Devender AS: Identification of eastern North American land snails. The Prosobranchia, Opisthobranchia and Pulmonata (Actophila). Walkerana 1980, 1:60-80.

47. Ozimec R, Bedek J, Gottstein S, Jalžić B, Slapnik R, Štamol V, Bilandžija H, Dražina T, Kletečki E, Komerički A, Lukić M, Pavlek M: Red book of Croatian cave dwelling fauna. Zagreb: Ministarstvo kulture, Državni Zavod za zaštitu prirode; 2009

48. Phillimore AB, Price TD: Density-dependent cladogenesis in birds. PLoS Biol 2008, 6:483-489.

49. Nee S, May RM, Harvey PH: The reconstructed evolutionary process. Philos Trans R Soc Lond B 1994, 344:305-311.

50. Etienne RS, Rosindell J: Prolonging the past counteracts the pull of the present: protracted speciation can explain observed slowdowns in diversification. Syst Biol 2012, 61:204-213.

51. Slatkin $\mathrm{M}$ : Isolation by distance in equilibrium and nonequilibrium populations. Evolution 1993, 47:264-279.

52. Pipan T, López H, Oromí P, Polak S, Culver DC: Temperature variation and the presence of troglobionts in terrestrial shallow subterranean habitats. J Nat Hist 2011, 45:253-273.

53. McGinnies WG, Goldman BJ, Paylore P: Deserts of the World. Tucson: Univ. Arizona Press; 1968

54. Edney EB, Franco P, Wool R: The responses of Arenivaga investigate (Dictyoptera) to gradients of temperature and humidity in sand studied by tagging with Technetium 99m. Physiol Zool 1978, 51:241-255.

55. Prozorova LA, Lee JS, Zasypkina MO, Korean Hypogean Malacofauna: First record in Asia of Troglobitic Zospeum-like snails (Pulmonata, Ellobioidea, Carychiidae). Korean J Soil Zool 2011, 15:1-4.

56. Barr TC Jr, Holsinger JR: Speciation in Cave Faunas. Annu Rev Ecol Syst 1985, 16:313-337.

57. Allegrucci G, Todisco V, Sbordoni V: Molecular phylogeography of Dolichopoda cave crickets (Orthoptera, Rhaphidophoridae): a scenario suggested by mitochondrial DNA. Mol Phylogenet Evol 2005, 37:153-164.

58. Davis GM: Evolution of prosobranch snails transmitting asian Schistosoma; coevolution with Schistosoma: a review. Prog Clin Parasitol 1993, 3:145-204.

59. Gittenberger E: What about non-adaptive radiation? Biol J Linn Soc 1991, 43:263-272

60. Aljančič G, Năpăruş M: Stygobionts washed out to surface: A case of Proteus anguinus. In Proceedings of 21st International Conference on Subterranean Biology: 2-7 September 2012. Edited by Pavol J. Slovakia: Kosice: Safarik University; 2012

61. Juan C, Guzik MT, Jaume D, Cooper SJB: Evolution in caves: Darwin's 'wrecks of ancient life' in the molecular era. Mol Ecol 2010, 19:3865-3880

62. Rona PA, Richardson ES: Early Cenozoic global plate reorganization. Earth Planet Sci Lett 1978, 40:1-11. 
63. Hsü KJ: Time and place in Alpine orogenesis - the Fermor lecture. Geological Society, London, Special Publications 1989, 45:421-443.

64. Sandberger F: Die Land- und Süsswasser-Conchylien der Vorwel. Wiesbaden: C.W. Kreidel; 1870:1870-1875.

65. Villatte J: Nouvelles donnéessur les mollusques continentaux du Thanétien inférieur sous-pyrénéen. Interprétation stratigraphique et paléoécologique. Geobios-Lyon 1979, 12:513-533.

66. Stworzewicz E: Miocene land snails from Belchatów (Central Poland), III: Carychiinae (Gastropoda; Pulmonata: Ellobiidae). Palaeont Z 1999, 73:261-276.

67. Bole J: Rod Zospeum Bourguignat 1856 (Gastropoda, Ellobiidae) Jugoslaviji. Die Gattung Zospeum Bourguignat 1856 (Gastropoda, Ellobiidae) in Jugoslawien. Razprave Slov Akad Znan Umetn 1974, 17:249-282.

68. Azuma M: Colored Illustrations of the Land Snails of Japan. Hoikusha, Osaka: Japan; 1982.

69. Bank RA, Gittenberger E: Notes on Azorean and European Carychium species (Gastropoda Basommatophora: Ellobiidae). Basteria 1985, 49:85-100.

70. Strauch E: Die Entwicklung der europäischen Vertreter der Gattung Carychium O.F. MÜLLER seit dem Miozän (Mollusca: Basommatophora). Arch Moll 1977, 107:149-193.

71. Folmer O, Black M, Heah W, Lutz R, Vrijenhoek R: DNA primers for amplification of mitochondrial cytochrome $C$ oxidase subunit I from diverse metazoan invertebrates. Mol Mar Biol Biotechnol 1994, 3:294-299.

72. Simon C, Frati F, Beckenbach A, Crespi B, Liu H, Flook P: Evolution, weighting, and phylogenetic utility of mitochondrial gene-sequences and a compilation of conserved polymerase chain-reaction primers. Ann Entomol Soc Am 1994, 87:651-701.

73. Colgan DJ, McLauchlan A, Wilson GDF, Livingston SP, Edgecombe GD, Macaranas J, Cassis G, Gray MR: Histone H3 and U2 snRNAsequences and arthropod molecular evolution. Aust J Zool 1998, 46:419-437.

74. Katoh K, Misasa K, Kuma K, Miyata T: MAFFT: a novel method for rapid multiple sequence alignment based on fast Fourier transform. Nucleic Acids Res 2002, 30:3059-3066.

75. Castresana J: Selection of conserved blocks from multiple alignments for their use in phylogenetic analysis. Mol Biol Evol 2000, 17:540-552.

76. Hebert PDN, Ratnasingham S, DeWaard JR: Barcoding animal life: Cytochrome c oxidase subunit 1 divergences among closely related species. Proc R Soc Lond B Biol Sci 2003, 270:S596-S599.

77. Puillandre N, Lambert A, Brouillet S, Achaz G: ABGD, Automatic Barcode Gap Discovery for primary species delimitation. Mol Ecol 2011, 21:1864-1877.

78. Pons J, Barraclough TG, Gomez-Zurita J, Cardoso A, Duran DP, Hazell S, Kamoun S, Sumlin WD, Vogler AP: Sequence-based species delimitation for the DNA taxonomy of undescribed insects. Syst Biol 2006, 55:595-609.

79. Monaghan MT, Wild R, Elliot M, Fujisawa T, Balke M, Inward DJG, Lees DC, Ranaivosolo R, Eggleton P, Barraclough TG, Vogler AP: Accelerated species inventory on Madagascar using coalescent-based models of species delineation. Syst Biol 2009, 58:298-311.

80. Hart MW, Sunday J: Things fall apart: biological species form unconnected parsimony networks. Biol Lett 2007, 3:509-512.

81. Drummond AJ, Rambaut A: BEAST: Bayesian evolutionary analysis by sampling trees. BMC Evol Biol 2007, 7:214.

82. Templeton AR, Crandall KA, Sing CF: A cladistic analysis of phenotypic associations with haplotypes inferred from restriction endonuclease mapping and DNA sequence data. III. Cladogram estimation. Genetics 1992, 132:619-633.

83. Clement M, Posada D, Crandall KA: TCS: a computer program to estimate gene genealogies. Mol Ecol 2000, 9:1657-1659.

84. Stamatakis A: RAxML-VI-HPC: maximum likelihoodbased phylogenetic analyses with thousands of taxa and mixed models. Bioinformatics 2006, 22:2688-2690

85. Nylander JAA: MrModeltest 2.3. Program distributed by the author. Uppsala: Evolutionary Biology Centre, Uppsala University; 2004.

86. Huelsenbeck JP, Ronquist F, Nielsen R, Bollback JP: Bayesian inference of phylogeny and its impact on evolutionary biology. Science 2001, 294:2310-2314.
87. Ronquist F, Huelsenbeck JP: MRBAYES 3: Bayesian phylogenetic inference under mixed models. Bioinformatics 2003, 19:1572-1574.

88. Baele G, Lemey P, Bedford T, Rambaut A, Suchard MA, Alekseyenko AV: Improving the accuracy of demographic and molecular clock model comparison while accommodating phylogenetic uncertainty. $\mathrm{Mol} \mathrm{Biol}$ Evol 2012, 29:2157-2167.

89. Raftery $A E$, Newton MA, Satagopan JM, Krivitsky PN: Estimating the integrated likelihood via posterior simulation using the harmonic mean identity. Memorial Sloan-Kettering Cancer Center, Dept. of Epidemiology \& Biostatistics Working Paper Series 2007, 6:1-45.

90. Turkheimer FE, Hinz R, Cunningham VJ: On the undecidability among kinetic models: from model selection to model averaging. J Cereb Blood Flow Metab 2003, 23:490-498.

91. Lartillot N, Philippe $\mathrm{H}$ : Computing bayes factors using thermodynamic integration. Syst Biol 2006, 55:195-207.

92. Xie W, Lewis PO, Fan Y, Kuo L, Chen M-H: Improving marginal likelihood estimation for Bayesian phylogenetic model selection. Syst Biol 2011, 60:150-160

93. Burnham KP, Anderson DR: Model Selection and Multi-Model Inference. New York: Springer-Verlag; 2002

94. Kass RE, Raftery AE: Bayes factors. J Am Stat Assoc 1995, 90:773-795.

95. De Loriol $P$, Jaccard $A$ : Etude géologique et paléontologique de la formation d'eau douce infracrétacée du Jura et en particulier de Villers-le-Lac. Mém Soc Phys et Hist Nat Genève 1865, 18:63-128.

96. Briart A, Cornet FL: Description des fossiles du calcaire grossier de Mons. Quatrième partie. Mem Acad r Sci Lett Belg 1889, 47:1-128.

97. Rambaut A, Drummond AJ: Tracer v1.4.: ; http://beast.bio.ed.ac.uk/Tracer.

98. Rabosky DL: Likelihood methods for detecting temporal shifts in diversification rates. Evolution 2006, 60:1152-1164.

99. Rabosky DL: LASER: a maximum likelihood toolkit for detecting temporal shifts in diversification rates from molecular phylogenies. Evol Bioinform Online 2006, 2:257-260.

100. Ree RH, Smith SA: Maximum likelihood inference of geographic range evolution by dispersal, local extinction, and cladogenesis. Syst Biol 2008, 57:4-14.

101. Phillips SJ, Anderson RP, Schapire RE: Maximum entropy modeling of species geographic distributions. Ecol Modell 2006, 190:231-259.

102. Hadly EA, Spaeth PA, Li C: Niche conservatism above the species level. Proc Natl Acad Sci USA 2009, 106:19707-19714.

103. Hijmans RJ, Cameron SE, Parra JL, Jones PG, Jarvis A: Very high resolution interpolated climate surfaces for global land areas. Int J Climato 2005, 25:1965-1978.

104. Waltari E, Hijmans RJ, Peterson AT, Nyári AS, Perkins SL, Guralnick RP: Locating Pleistocene refugia: comparing phylogeographic and ecological niche model predictions. PLoS One 2007, 2:e563.

105. Pearson RG, Raxworthy CJ, Nakamura M, Peterson AT: Predicting species distributions from small numbers of occurrence records: a test case using cryptic geckos in Madagascar. J Biogeogr 2007, 34:102-117.

106. Fielding $A H$, Bell JF: A review of methods for the assessment of prediction errors in conservation presence: absence models. Environ Conserv 1997, 24:38-49.

107. Warren DL, Glor RE, Turelli M: ENMTools: a toolbox for comparative studies of environmental niche models. Ecography 2010, 33:607-611.

108. Schoener TW: Anolis lizards of Bimini: resource partitioning in a complex fauna. Ecology 1968, 49:704-726.

109. Warren DL, Glor RE, Turelli M: Environmental niche equivalency versus conservatism: Quantitative approaches to niche evolution. Evolution 2008, 62:2868-2883

110. Warren DL, Seifert SN: Ecological niche modeling in Maxent: the importance of model complexity and the performance of model selection criteria. Ecol Appl 2011, 21:335-342.

111. Holm G: Exotic species of land snails from Mount Vernon, WA and Queen Elizabeth Park, Vancouver, B.C. Dredgings 2010, 50:3-4.

112. Roth B: European land mollusks in the San Francisco Bay area, California: Carychium minimum Müller and the Arion hortensis complex. Veliger 1982, 24:342-344.

113. Forsyth RG: Land Snails of British Columbia. Royal BC Museum Handbook. Victoria: Royal British Columbia Museum; 2004 
114. Forsyth RG, Oldham MJ, Schueler FW: Mollusca, Gastropoda, Ellobiidae, Carychium minimum, and Ferussaciidae, Cecilioides acicula: Distribution extension and first provincial records of two introduced land snails in Ontario, Canada. Check List 2008, 4:449-452.

115. Grimm FW, Forsyth RG, Schueler FW, Karstad A: Identifying Land Snails and Slugs in Canada: Introduced Species and Native Genera. Canadian Food Inspection Agency: Ottawa; 2009.

116. Clapp WF: Carychium minimum Mull. Nautilus 1912, $26: 24$.

doi:10.1186/1471-2148-13-18

Cite this article as: Weigand et al:: Evolution of microgastropods

(Ellobioidea, Carychiidae): integrating taxonomic, phylogenetic and

evolutionary hypotheses. BMC Evolutionary Biology 2013 13:18.

\section{Submit your next manuscript to BioMed Central and take full advantage of:}

- Convenient online submission

- Thorough peer review

- No space constraints or color figure charges

- Immediate publication on acceptance

- Inclusion in PubMed, CAS, Scopus and Google Scholar

- Research which is freely available for redistribution 